\title{
Revision of the genus Trichomeloe Reitter, with the description of new species and first instar larvae (Coleoptera: Meloidae)
}

\author{
Marco A. Bologna, Andrea Di Giulio \\ Dipartimento di Biologia, Università degli studi Roma Tre, Viale Marconi, 446 - 00146 Roma, Italy, bologna@, \\ uniroma3.it,digiulio@uniroma3.it
}

Key words: bionomics, distribution, key, larval morphology, new species, synonymies, taxonomy

\begin{abstract}
The Palaearctic genus Trichomeloe is reviewed and newly defined on the basis of larval and adult characters. Its position among the Lyttini tribe is discussed. Trichomeloe includes eight species, mostly from the Near East. The bionomics of the genus is summarized, together with a key to the species, an annotated catalogue and some taxonomic remarks. T. syriacus n. sp. from Syria and T. mesopotamicus n. sp. from northern Irak, are described. The first instar larva of T. syriacus is described and compared with that of $T$. chrysocomus, both figured by scanning electron microscopy photographs.
\end{abstract}

\section{Contents}

Introduction 227

Material and methods ……........................................... 228

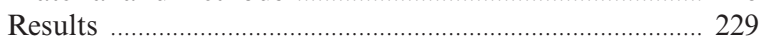

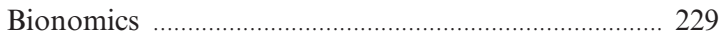

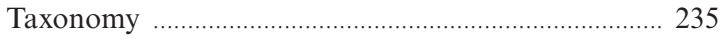

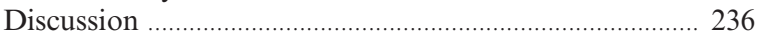

Acknowledgements ..................................................... 237

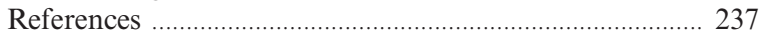

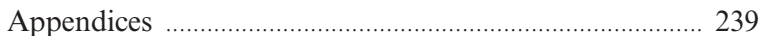

\section{Introduction}

The taxon Trichomeloe (Fig. 1) was described by Reitter (1911) as a subgenus of Meloe Linnaeus, 1758 , a wingless and brachyelytrous genus of the tribe Meloini, largely distributed in the Holarctic, eastern and Southern Africa, and marginally in the Oriental Region. Reitter (1911) did not designate a type species and included in Trichomeloe five species, previously referred to Meloe by Escherich (1890) as the "behaarten Meloe-Arten" group, a polyphyletic assemblage, which almost completely belongs to Meloe, subgenus Eurymeloe Reitter, 1911.
Cros (1934) described the first instar larva of "Meloe" chrysocomus Miller, 1861, one of the species considered by Reitter (1911) as Trichomeloe, and noted its lyttine morphology, similar to that of "Meloe" majalis Linnaeus, 1758, a Western Mediterranean species. Afterwards, Cros (1940) distinguished chrysocomus, majalis and affinis Lucas,

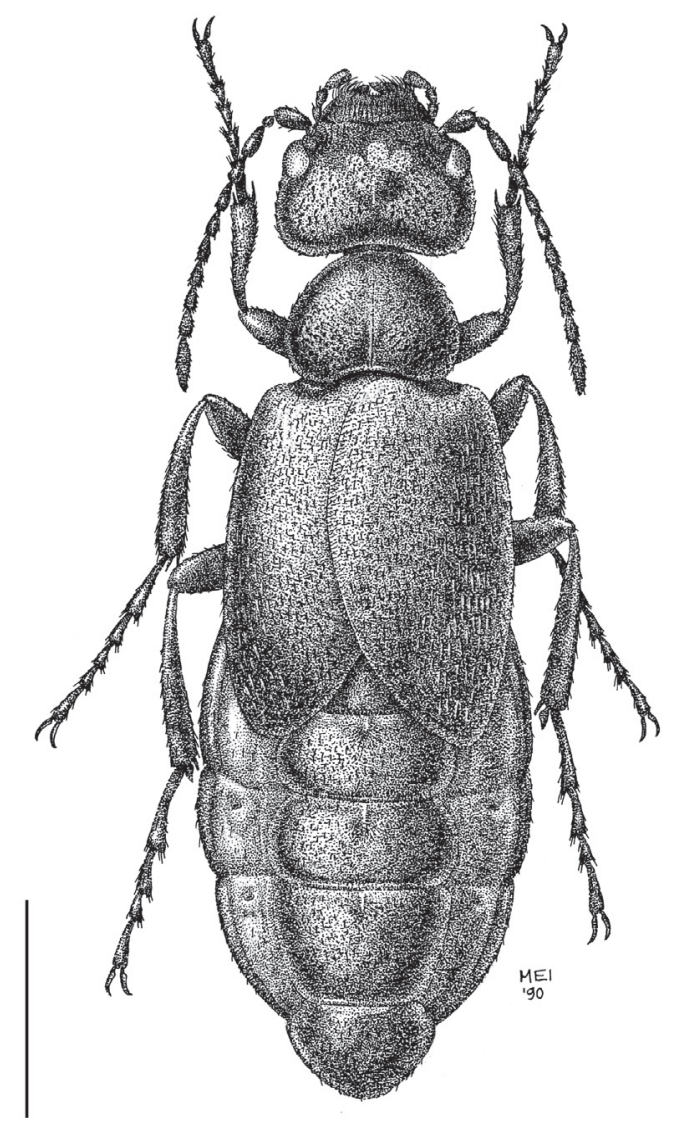

Fig. 1. Trichomeloe sericellus, male dorsal habitus (from Bologna, 1991). Scale bar $=5 \mathrm{~mm}$. 
1849, another Maghrebian species, from typical Meloe because of larval characters, considering them as Lyttini but without description of a new taxon. This systematic opinion was adopted by MacSwain (1956), who separated these three species from Meloe, and formalized the new status of Trichomeloe by selecting Meloe chrysocomus as type species. Conversely, Pardo Alcaide (1952), Kaszab (1958, 1961, 1969) and Aksentjev (1988), conserved the traditional taxonomic arrangement and considered Trichomeloe as a subgenus of Meloe.

Recently, Bologna (1989) removed majalis from Trichomeloe and placed it in the new genus Berberomeloe based on adult and larval characters. Both genera were treated as Lyttini (see also Bologna, 1988, 1989, 1991). Selander (1991) also judged both genera as distinct and included them in the tribe Cerocomini, subtribe Lyttina. Placement in the tribe Lyttini was supported by Bologna andPinto (2001, 2002), who noted considerable variability of larval morphology in the tribe and suggested its possible polyphyly (see also Bologna et al., 2008). A second species of Berberomeloe, B. insignis (Charpentier, 1818), endemic to southern Spain, was recently resurrected by Garcia-Paris (1998); this has been supported by molecular and larval evidence (Settanni et al., unpublished).

Following the literature (Escherich, 1890, pars; Reitter, 1911; Kaszab, 1958), Bologna (1988, 1989) referred six Meloe species to the genus Trichomeloe: T. chrysocomus Miller, 1861; T. conicicollis Reitter, 1907; T. deflexus Reitter, 1889; T. pubifer Heyden, 1887; T. sericellus Reiche, 1857; T. ottomanus Pliginskij, 1914. He also synonymized T. frivaldszkyi Kaszab, 1958 with T. ottomanus, and excluded T. affinis, referring it to Meloe (Eurymeloe). Afterwards, the same author (Bologna, 1991) excluded pubifer from Trichomeloe, referring also it to Meloe (Eurymeloe), after the examination of one syntype (MNHN: Reitter collection). In addition, Pripisnova (1987) described Meloe (Trichomeloe) ovatus from Tajikistan. The range of ovatus is isolated from that of other Trichomeloe, but some characters, figured in the short description, as the male genitalia (both parameres and aedeagus) and the pronotum shape, support the inclusion of T. ovatus in this genus. The range of the entire genus Trichomeloe appears consequently divided in two disjunct sub-ranges, respectively in the Eastern Mediterranean and Central Asia. At present, the following six species are referred to Trichomeloe: T. chrysocomus, T. conici- collis, T. deflexus, T. sericellus, T. ottomanus, T. ovatus.

Escherich (1890) and Reitter (1895) published partial keys to the Trichomeloe species, but mixed them with species actually belonging to Meloe (Eurymeloe). Several species are phenetically very similar and females are difficult to identify; for this reason an updated key was necessary.

Aims of this paper are to: (a) summarize adult and larval bionomics; (b) compare larval morphology of two species, one of which described for the first time and both figured by scanning electron microscopy photographs; (c) propose a classification of species and define natural groups; (d) construct an identification key to the species; (e) collect all taxonomic remarks and distributional information in an annotated catalogue; (f) describe two new species from Syria and Mesopotamia respectively.

\section{Material and methods}

For the present study 407 adults of Trichomeloe were examined: 85 of T. chrysocomus (Miller, 1861); 27 (holotype included) of T. conicicollis (Reitter, 1907); 96 (holotype and 1 paratype included) of $T$. deflexus (Reitter, 1889); 14 (holotype and 11 paratypes included) of T. mesopotamicus n. sp.; 7 (holotype and 1 paratype of the synonym frivaldszky included) of T. ottomanus (Pliginskji, 1914); 173 of T. sericellus (Reiche, 1857); 5 (holotype and 3 paratypes included) of T. syriacus n. sp. We tried to examine the holotype and the paratypus of T. ovatus, probably both preserved in the Tajikistan University Museum, but were unsuccessful and consequently no specimens of $T$. ovatus were studied.

Ecological observation on habitat preference, altitudinal range, host plants, etc., were obtained in the field in Turkey, Syria, Palestine, Jordan; other records have been deduced from the literature or from collection labels.

One female of T. syriacus from Syria, Palmyra (collected on January $30^{\text {th }} 1998$ by P. De Salvo), laid (on February $4^{\text {th }} 1998$ ) one egg mass in the rearing box; eggs were kept in a thermostatic cell with photoperiodic control under ca $24-25^{\circ} \mathrm{C}$. First instar larvae hatched two and half weeks later in Italy, at University laboratory, in two consecutive days (February $21 / 22^{\text {nd }} 1998$ ), and then fixed in $70 \%$ ethanol. One female of T. chrysocomus from Jordan, KérakCa Province, Wadi Al Hasa (collected on January 
$2^{\text {nd }} 2005$ by P. Bombi), laid (on January $17^{\text {th }} 2005$ ) one egg mass in the rearing box; eggs were kept in the same conditions described above and first instar larvae hatched in two days (January 26 and $28^{\text {th }}$ 2005).

The description of the first instar larva of $T$. syriacus from Palmyra is based on 15 triungulins preserved in 70\% ethanol in the CB (vial 398), one of which cleared and mounted in Canada balsam on slide M340, and some prepared for SEM microscopy, after critical point dehydration and gold sputtering. Additionally, 2 triungulins of T. chrysocomus, from Palestine mounted on slide M183 (now in CB, from several BMNH specimens in $70 \%$ ethanol), and several triungulins from Wadi Al Hasa preserved in $70 \%$ ethanol in the CB (vials 546, 547), some of which prepared for SEM microscopy, have been observed for comparison. The morphological analyses were made by using a Leitz Laborlux S light microscope and a Philips XL30 scanning electron microscope (L.I.M.E., University "Roma Tre", Rome). The terminology of larval structures follows MacSwain (1956), Lawrence (1991), and Bologna and Pinto (2001). Certain characters used in the larval chaetotaxy were adopted from notational conventions suggested by Selander (1990) and Bologna and Di Giulio (2002).

\section{Results}

\section{Bionomics}

Before the description of T. ovatus, this genus was considered endemic to the eastern Mediterranean. The main sub-range of the genus includes the southern Anatolia (W to Fethyie, Muğla Province, and to the Greek island of Castelorizon, North to Elazig, and East to the Sanli Urfa Province), Cyprus, the entire Levant, $\mathrm{S}$ to the North Negev and $\mathrm{E}$ to the northern Iraki Mesopotamia (the new species $T$. mesopotamicus). A second and isolated sub-range, includes only one locality of the extreme southern Tadjikistan. Specimens of T. sericellus from Crimea and Sicily (see Appendix I) represent very doubtful records or relict populations that were never confirmed.

There is minimal information on habitat and other ecological preferences. Almost all the species are adapted to Turanian steppe or semi-desert habitats, and only T. conicicollis and some Western pop- ulations of T. chrysocomus and T. deflexus from the Hatay and Adana provinces (Turkey), are living in Mediterranean habitats, particularly in pastures derived from Pinus halepensis forests or maquis. No information is available on the habitat preference of T. ovatus (see type locality of this species).

Most collection sites are located on plains or in hilly areas, but the altitudinal distribution varies from the sea level to more than $1500 \mathrm{~m}$ a.s.l. In particular, T. chrysocomus was collected from about 600 to 1600 m a.s.1. on the Nemrud Dagi (SE Turkey); T. conicicollis from sea level to about $200 \mathrm{~m}$ a.s.1.; T. deflexus from $-150 \mathrm{~m}$ (Dead Sea Valley) to about $1000 \mathrm{~m}$ a.s.1.; T. mesopotamicus from about 50 to $300 \mathrm{~m}$ a.s.1.; T. ottomanus to at least $1000 \mathrm{~m}$ a.s.l.; T. sericellus from about - $50 \mathrm{~m}$ (Dead Sea Valley) to about $2000 \mathrm{~m}$ a.s.l. on Lebanon Mts; T. syriacus from 400 to about $1100 \mathrm{~m}$ a.s.1.

Adults are lucifugous and probably also nocturnal, because they are usually found under stones (see also Bodenheimer, 1934); no information is available on their food preference, but probably adults feed on prostrate Asteraceae or on Poaceae, as the wingless species of the genera Meloe and Berberomeloe. Adult occurrence appears to be primarily restricted to late winter and spring. The following adult occurrence is documented: T. chrysocomus from early March to the first half of May, with few records in January and November; T. conicicollis from the second half of April to the first half of May and one record in September; T. deflexus from January to April, with a few records from October to December; T. mesopotamicus in April and May; T. ottomanus one single record in the late March; $T$. ovatus two records, respectively in March and April; T. sericellus from January to March, with few records in December and April; T. syriacus from January to March.

Sahlberg (1913) listed one female of T. sericellus digging a oviposition hole in the ground as it is typical of other genera of Lyttini, and more generally in the Meloinae subfamily. This behaviour was personally observed in captivity in both $T$. chrysocomus and T. syriacus. The first instar larva lasts 9-11 days in T. chrysocomus (about 20, according to Cros, 1934) and 17-18 days in T. syriacus. No information is available on the later larval instars and the development and hosts are unknown. According to its morphology, the triungulin is not phoretic, but probably reaches the nest of a bee species, as in other Lyttini genera. 
The first instar larva of Trichomeloe. - Compared to other lyttine larvae, triungulins of the genus Trichomeloe lack distinct autapomorphies, except for the peculiar shape of labial palpomere II (Figs 4e4f), flattened, asymmetrical and slightly enlarged from base to apex. First instar larvae are recognizable by the following combination of characters: larva slightly flattened, setae everywhere short, head rounded, antennae short with large, bulbous and pointed hyaline vesicle (sensorium), mandibles laterally corrugated with smooth cutting edge, maxillary palpomere III flattened, spoon-like, presence of medial tuft of filiform cuticular structures on epipharynx, long ligular setae, last abdominal sternites completely sclerotized, caudal setae relatively short.

Description of first instar larva of Trichomeloe syriacus. - Habitus. Triungulin campodeiform; body elongate, subcylindrical, slightly flattened, subparallel-sided, slightly constricted at metathorax and tapered at abdominal apex (segments VIII and IX).

Colour. Uniform brown due to similar sclerotization of head, tergites, sternites, legs and pleurites; lighter posterior area present on meso and metanotum.

Microsculpture. Cuticle reticulate with irregular poligonal meshes.

Measurements. Body length $1.9 \mathrm{~mm}$ (from pygidium to labrum); head length $0.3 \mathrm{~mm}$ (from occipital foramen to clypeolabral suture), maximum width $0.4 \mathrm{~mm}$, width at base (occipital foramen) $0.3 \mathrm{~mm}$; basal stem of epicranial suture $0.09 \mathrm{~mm}$; diameter of stemma $0.015 \mathrm{~mm}$; antennal length $0.08 \mathrm{~mm}$; antennal terminal seta length $0.18 \mathrm{~mm}$; sensorium length $0.04 \mathrm{~mm}$, maximum width $0,03 \mathrm{~mm}$; labrum width $0.14 \mathrm{~mm}$; prothorax length $0.25 \mathrm{~mm}$, maximum width $0.46 \mathrm{~mm}$; abdomen length $1,0 \mathrm{~mm}$, maximum width $0.5 \mathrm{~mm}$; abdominal terminal setae length $0.4 \mathrm{~mm}$; diameter of spiracles: mesothoracic $0.034 \mathrm{~mm}$, abdominal I-VIII respectively from 0.03 $\mathrm{mm}$ to $0.015 \mathrm{~mm}$.

Head (Figs 3a-3b). Rounded, wider than long (width/length $=1.33$ ), subparallel sided, narrowed towards base; basal elevation absent; anterior margin of head slightly convex. Epicranial suture $\mathrm{Y}$ shaped; frontal sutures complete to antennal fossae, widely diverging at base (angle about $90^{\circ}$ ), then parallel and markedly curved laterally at distal third; basal stem of the epicranial suture very long. One small stemma present on each side of head capsule, dorsally placed, slightly convex, irregularly rounded, about half diameter of mesothoracic spiracle. Frontoclypeal region with a total of 14 setae subequal in length; boundary between clypeus and frons with a transverse row (frontoclypeal row, FCR) of 3 pairs of setae; sensory pit between FCR and $\mathrm{FCR}_{3} ; 4$ pairs of setae posterior to $\mathrm{FCR}$, following a curved line paralleling the arms of the epicranial suture (from posterior to anterior setae 1-4); sensory pits present between setae 1 and 2; each epicranial plate, dorsally on posterior half, with 4 very small setae longitudinally arranged in the middle of the plate, with 1 pit at side; 1 seta and 1 anterior pit close to the base of frontal arms, and 3 setae about at the same level lined laterally; 3 setae at the level of stemma: two medial (the closest to the stemma long being the ocular seta, the other short) and one lateral to the stemma; one short seta anteriorly, just behind antennal fossa; ocular sensory pit distinctly anterior to ocular seta and to stemma. Epicranial plate ventrally with 5 setae ( 3 lined at the level of hypostomal ridge, 2 anterolateral at margin) and 3 pits ( 2 at each side of mandibular articulation and 1 medial). Gulamentum weakly sclerotized with 2 short anterior setae. Antennae (Fig. 3c) short, laterally directed; antennomere I short, ring-like with 1 dorsal and 1 dorso-lateral sensory pits; II slightly shorter than I and slightly asymmetric, with 3 elongate ( 2 dorsolateral and 1 medioventral) and 1 very short seta (dorsally, at the base of sensorium), and 2 dorsal pits; sensorium on segment II ventral, large, bulbous, acute at apex, nearly as long as antennomere III and as wide as antennomere II; antennomere III cylindrical, slightly enlarged toward apex, about as long as antennomere I and II together, with a long apical seta (about 3 times as long as entire antenna); 3 subapical setae, 2 dorsolateral and 1 medioventral; one small seta near the base of apical seta, and 1 small medial pit on outer side of the segment. Labrum transverse, with straight anterior margin and rounded sides, with 9 pairs of setae of different sizes and 2 pits, mostly lined along the anterior margin. Epipharynx with slightly protruding medial tuft of elongate cuticular structures (Fig. $3 d$ ), surrounded by about 10 pairs of small sensilla. Mandibles (Fig. 3f) robust, with smooth cutting edge, distinctly excavated ventrally; outer margin of mandible distinctly longitudinally furrowed, with 2 lateral setae and 2 sensory pits dorsally lined with the distal seta. Maxillae (Fig. 3e) with 4 setae on stipes, 2 longer distally, and 2 shorter more basal, 


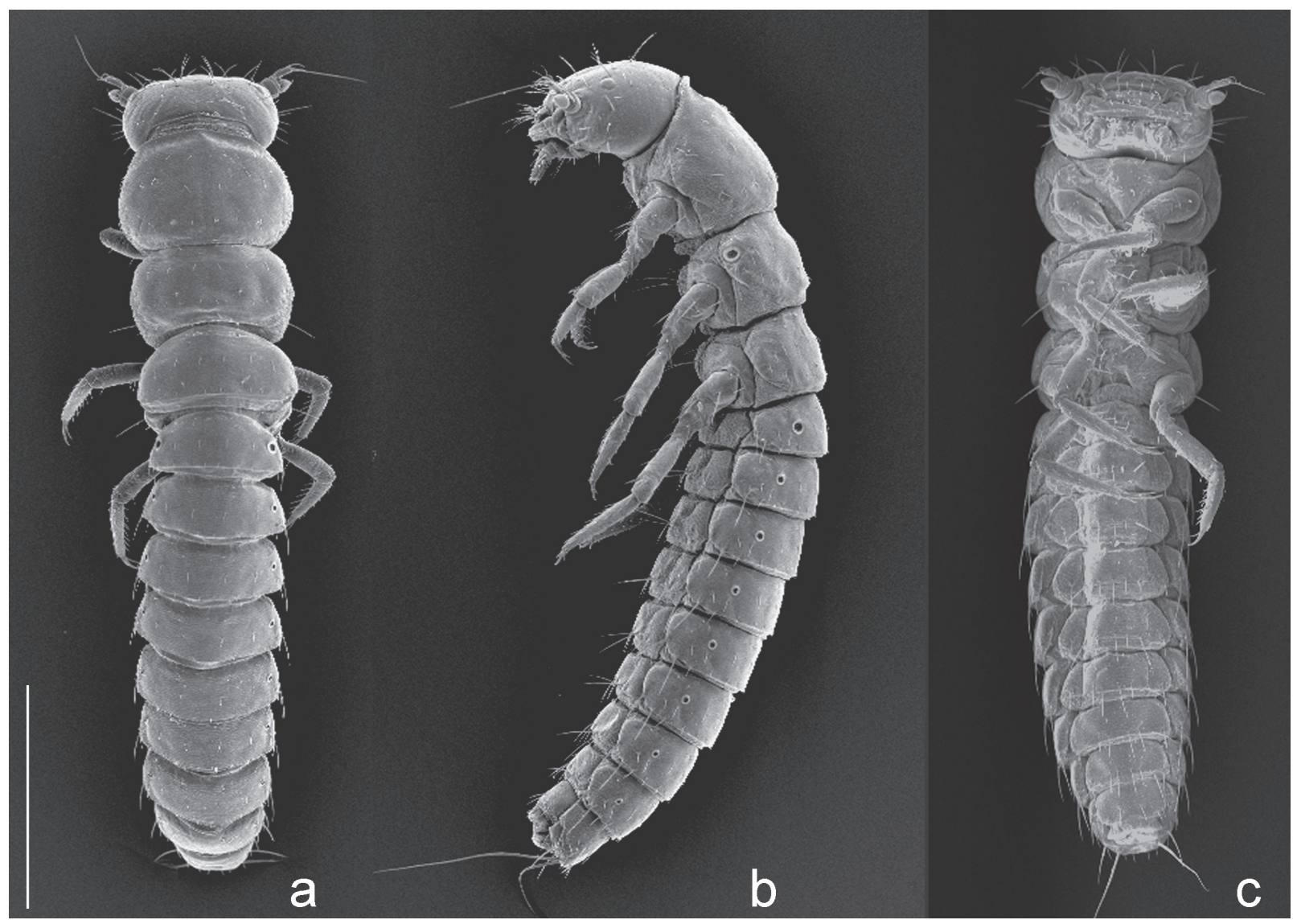

Fig. 2. Trichomeloe chrysocomus, first instar larva: a) habitus, dorsal view; b) habitus, left lateral view; c) habitus, ventral view. Scale bar $=500 \mu \mathrm{m}$.

and 2 pits, one medial and 1 basal; mala simple, lobiform, protruding, with 8-10 thick, pointed setae; maxillary palpomere I short, ring-like, with 1 very small lateral seta and 1 pit ventrally; palpomere II with 2 setae at the two sides, outer seta reaching half palpomere III; palpomere III subrectangular, asymmetric, flattened (somewhat spoon-like), longer than I and II together, with 1 elongate medial seta basally and 1 apical thin sensorial area widely extending on inner margin, composed by 1 long sensory appendix, inserted in a prominent base, and about 20 shorter papillae; outer margin of palpomere III with 1 slender digitiform sensillum and 1 pit; cardo small, transverse, with 1 very small seta almost on lateral membrane. Labium (Fig. 3b) with mentum bearing 2 basal pairs of small setae and 1 pair of sensory pit basally; prementum with 1 pair of setae medially and 1 pair of small setae basally; dorsal subapical pair of ligular setae (Fig. 3d) elongate, between the insertions of labial palpi; labial palpi with outer margin slightly longer than inner margin; palpomere I short and broad, with ventrolateral small seta, II flattened, about twice longer than I, with an apical sensory complex similar to that of maxillary palpomere III but with sensory appendix shorter and stout; 1 sensory pit lateroventrally (outer side).

Thorax. Segments transverse, subrectangular, decreasing in width from prothorax to metathorax, with straight anterior and lateral margins and slightly curved posterior margins. Ecdysial line well marked and complete on pro- and mesonotum and absent on metanotum. Pronotum slightly broader than head, 1.84 times wider than long; 13 setae (12 long and 1 short) and 3 pits present symmetrically at each side of the ecdysial line, approximately disposed in 3 transverse, subparallel rows; anterior row (AR) with 4 setae and 4 pits (1 small anterolateral seta on membrane); medial row (MR) with 3 setae and 1 small anteromedial pit, and posterior row 

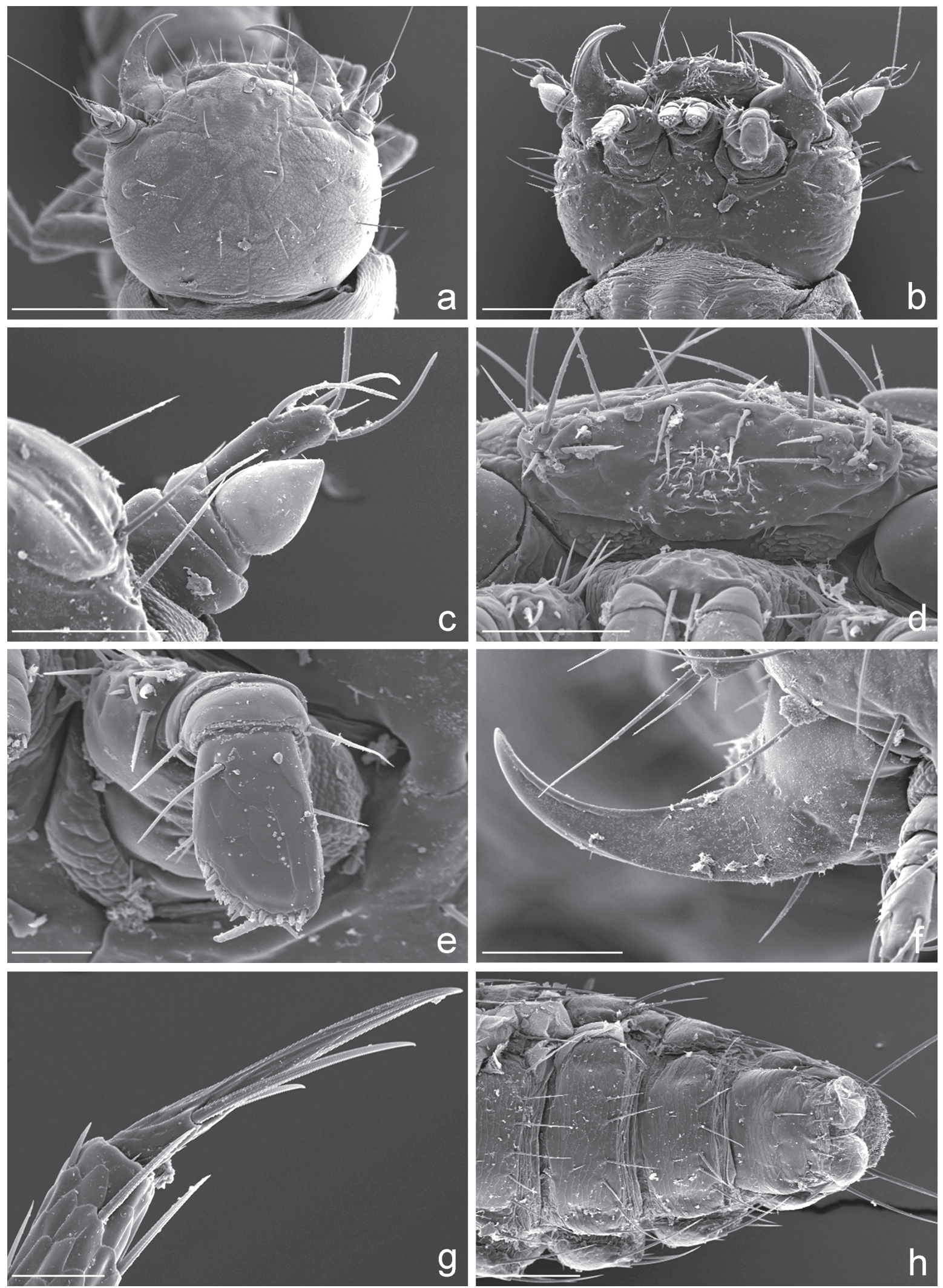
(PR) with 5 setae and 2 pits; prosternum with 3 pairs of medial setae of different length, medial pair shorter and posterior pair longer than anterior pair; 4 pairs of small setae lateral to prosternum ( 2 pairs lateral at the base of coxa, one anterior and one posterior) and 2 pairs of small setae anteriorly on neck ventral membrane. Mesonotum with AR composed of 5 setae, small compared to those of pronotum and 1 slightly posterior pit; MR with 5 setae ( 2 near the stigma); PR with 5 short setae and 2 pits; 3 pairs of medial setae on mesosternum increasing in length from anterior to posterior, posterior pair very long. Setae of metathorax similar in number, position and relative dimensions to those of mesothorax.

Legs. Slender; coxa short and subconical, with on anterior side: 3 long setae, transversally lined (gradually decreasing in size from the external to the internal), 2 small setae basal and 1 pit subapical; outer side with 1 extremely small seta; inner side with 1 subapical seta and 1 pit; throcanter with 3 setae and 4 pits; 6 setae and 1 pit on femur, the major ventral femoral seta, much shorter than femur; tibiotarsi and claws increasing in length from fore to hind leg; tibiotarsus with 4 longitudinal rows of 4-7 spiniform setae; claws (Fig. 3g) thin, acute and only slightly curved at apex, with 2 sub-basal setae of different length, slightly displaced at base, the distal longer than the proximal seta and approaching apex; surface of claws longitudinally corrugated.

Spiracles. Rounded, internally papillate and spongy; marginal ring (peritreme) slightly protruding and medially denticulate; mesothoracic spiracle anterolateral, about twice as large as the stemma, suboval; abdominal spiracles dorsolateral, on tergites; abdominal spiracle I larger than others and more displaced dorsally; II-VI subequal in size, VIIVIII smaller.

Abdomen (Fig. 3h). Flattened, subparallel sided with transverse, well sclerotised, rectangular terga; abdominal segments VIII-IX distinctly smaller; tergum completely fused with laterotergites on segments IX, only partially or not fused with laterotergites on segments II-VIII (suture well visible at light

Fig. 3. Trichomeloe syriacus, first instar larva: a) head, dorsal view; b) head, ventral view; c) left antenna, ventral view; d) labrum, ventral view; e) left maxillary palpomeres; f) left mandible, dorsal view; g) prothoracic claw, anterior view; h) apex of abdomen, ventral view. Scale bars: $a=200 \mu \mathrm{m} ; \mathrm{b}, \mathrm{h}$ $=100 \mu \mathrm{m} ; \mathrm{c}, \mathrm{d}, \mathrm{f}=50 \mu \mathrm{m} ; \mathrm{e}=20 \mu \mathrm{m}$. microscope). Two long posterior setae on laterotergites. Terga with approximately 3 rows of setae transversely lined at each side of the midline; 2 (one medial and 1 lateral) small setae ( 4 on tergum I) and 1 pit on AR; 2 short medial setae on MR; 6 short setae and 1 submedial pit on PR. PR of tergum IX with second pair from the midline (caudal setae) elongate, about as long as the last three segments. Sternites (Fig. 3h) gradually enlarging from segment I to VII, covering all sternum on segments VII-IX. Each side of sterna with AR and MR with 1 short seta each, and PR with 4 (3 on sternum I) longer setae (the external pair on lateral membrane on segments I-VI). Segment X membranous, tergum with some very small setae transversally lined, difficult to count at microscope; sternum longitudinally divided in 2 rounded lobs (pygopods, Fig. 3h), moderately produced.

Comparison with the triungulin of $\mathrm{T}$. chrysocomus. - T. syriacus is very similar to T. chrysocomus (see Cros, 1934; new observation on Wadi Al Hasa specimens, Figs 2a-2c, 4a-4h) for most characters except for the followings: head capsule, thoracic and abdominal segments wider ((i) ratio head capsule width/length: $T$. syriacus $=1.6 ; T$. chrysocomus $=$ 1.2; (ii) ratio maximal pronotum width/length: $T$. syriacus $=1.8 ; T$. chrysocomus $=1.6$; (iii) ratio $\max$ imal width/length of I abdominal segment: $T$. syriacus $=4.1 ;$ T. chrysocomus $=3.5)$ ) with straight and subparallel lateral margins; legs slightly shorter; abdomen distinctly tapered only at the last two segments; frontal sclerite basally narrower (ratio length of sclerite/width of sclerite at basis: $T$. syriacus $=$ 1.0; T. chrysocomus $=1.8$ ); basal stem of the epicranial suture slightly shorter (ratio frontal sclerite/epicranial suture length: $T$. syriacus $=1.9 ; T$. chrysocomus $=1.5)$; stemmata about two times wider; antennomere III slightly shorter (ratio antenna/antennomere III lenght: $T$. syriacus $=2.0 ; T$. chrysocomus $=2.1$ ); and more clavate at apex; spiracles wider; mesothoracic spiracle more oval; caudal setae slightly longer (ratio caudal seta/body length: $T$. syriacus $=0.2 ;$. . chrysocomus $=0.1)$.

Larval features and comparison with other Lyttini genera. - The triungulin of the genus Trichomeloe is a typical non-phoretic larva, very similar to that of other genera of Lyttini. The setae are everywhere short and the chaetotaxy is typical of a lyttine first instar larva, except for a greater length of the ligular 

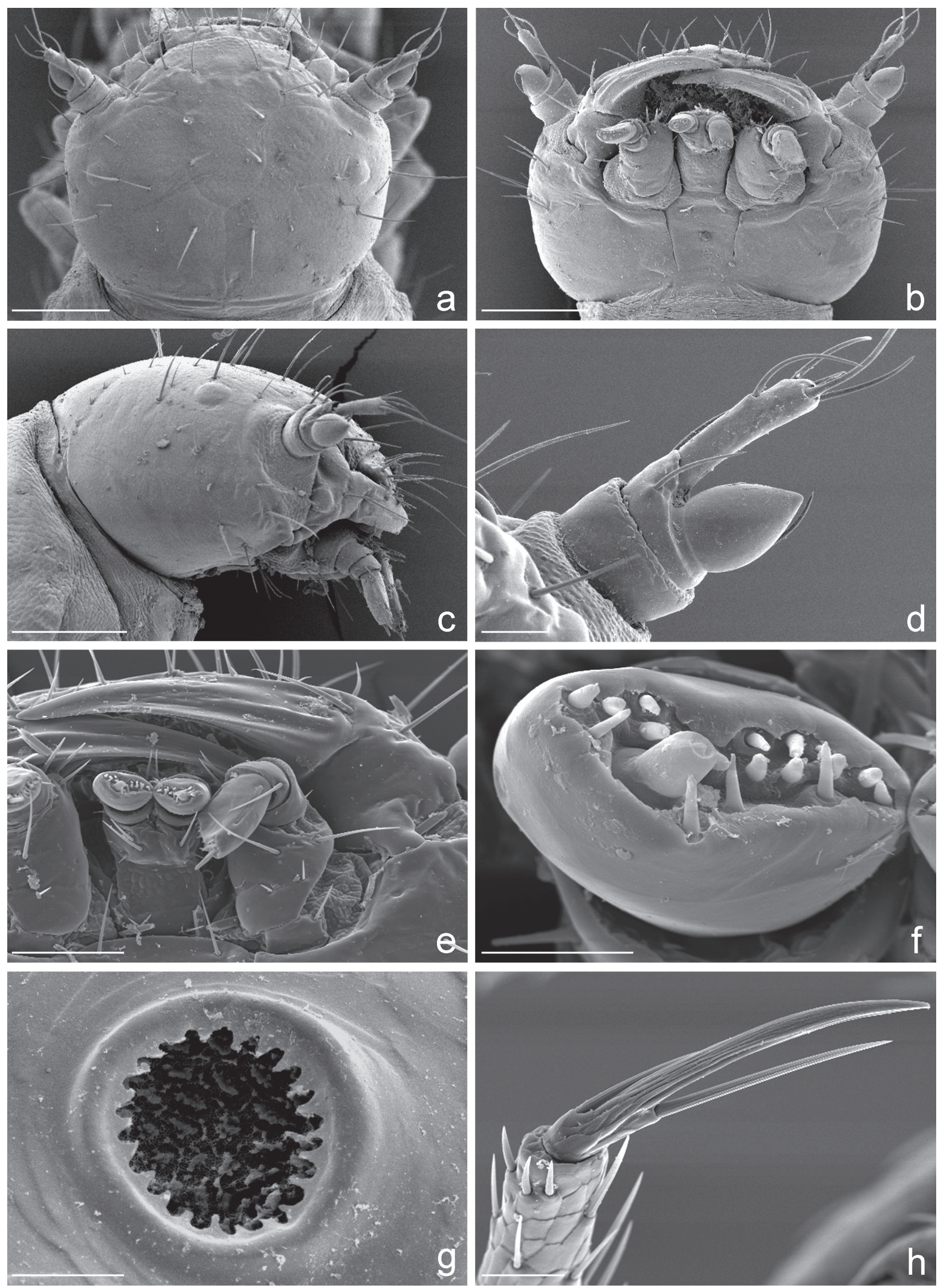
setae. The medial tuft of filiform cuticular structures on epipharynx seems to be unique in Lyttini, and convergent to those of several genera of the tribe Meloini. Characteristic of this genus is the presence of flattened, spoon-like maxillary palpomere III, with thin and asymmetrical apical sensorial area, by long, stick-like sensory appendix also present in the genera Lydus, Alosimus, Oenas, Lytta and Teratolytta. Apotypic is the modification of the second labial palpomere, flattened and subrectangular, instead of cylindrical, as in most lyttine genera.

The Trichomeloe triungulin shares with Berberomeloe the following characters: head rounded, distinctly sculptured with irregular polygonal meshes, mandibles longitudinally corrugated on outer side (also in Alosimus and Lydomorphus), abdominal sternites well developed and sclerotized, similar shape and relative size of spiracles (denticulate peritreme and funnel-shaped atrium). Trichomeloe differs from Berberomeloe by the relative length of the antennomeres (Trichomeloe with antennomeres I and II shorter and wider), antennomere II with different sensory appendix (in Trichomeloe larger, more bulbous and more pointed), relative size of setae on antennomere II; shape of fore- and mesofemoral setae, presence of abdominal laterotergites, position of abdominal spiracle I, and tergal sclerotization of abdomen resulting in a different colouration of the body (uniform brown in Trichomeloe and two-coloured, yellow-black, in Berberomeloe).

\section{Taxonomy}

Genus diagnosis. Integument black or piceous, head partially red; body setation usually dense, light or rarely mixed light and black. Size: 8-25 mm (Fig. 1). Head only slightly convex or quite flat, temples more or less parallel, occiput usually rounded, elongate in a single species; red frontal spot in one species more or less extended posteriorly on sides, at least on temples; punctures variously in size and

Fig. 4. Trichomeloe chrysocomus, first instar larva: a) head, dorsal view; b) head, ventral view; c) head, right lateral view; d) left antenna, ventral view; e) mouthparts, left side, ventral view; f) apical sensorial area on right labial palpomere II; g) right abdominal spiracle I; h) prothoracic claw, dorsal view. Scale bars: $\mathrm{a}-\mathrm{c}=100 \mu \mathrm{m} ; \mathrm{d}, \mathrm{h}=20 \mu \mathrm{m}$; e $=50 \mu \mathrm{m} ; \mathrm{f}, \mathrm{g}=10 \mu \mathrm{m}$. deep. Eleven antennomeres, cylindrical, XI distinctly longer than others; male with or without a modified area (possibly sensory or glandular) on antennomeres III-VII; setation denser and shorter on the last four or five segments. Labrum widely emarginated; mandibles robust and evidently curved; maxillary and labial palpi not modified, last palpomere subsecuriform. Pronotum reniform in one species more conically extended anteriorly, more or less bulged on sides at base, slightly longitudinally depressed in the middle, more or less depressed along the base; prosternum widened on sides; mesonotum not visible dorsally under the pronotum; mesosternum short, wide, anteriorly not modified; metasternum short, wide; elytra usually distinctly setose, imbricate at base, shorter than abdomen, which clearly emerge posteriorly; legs robust and densely setose, tarsomeres elongate, not modified in male; metacoxae partially covered by the middle ones; spurs of pro- and mesotibiae both slender and pointed, the external spur of metatibiae widened and spoon-like, the inner one stick-like; claws smooth. Abdominal tergites broadly sclerotized; sternites not modified; posterior margin of the male penultimate sternite sinuate in the middle, that of the last one deeply V-incised in the middle, rounded in female. Male gonostyli in lateral view more or less clylindrical in the basal half, with apical lobes more or less narrowed and with short setae; phallobase short, usually wide in dorsal view; aedeagus with two ventral hooks or only with one in two species ( $T$. chrysocomus, T. conicicollis).

Trichomeloe belongs to the subfamily Meloinae because of the larval characters (see Bologna and Pinto, 2001) and the mouthparts, claws and male genitalia structure of adult (Bologna, 1991). Larval characters are similar to those of several genera referred to the Lyttini, one lineage which, according to morphological (Bologna and Pinto, 2001) and molecular (Bologna et al., 2008) analyses seems to be polyphyletic. The real phylogenetic affinities of Trichomeloe relative to other genera of Lyttini remain uncertain, as discussed by Bologna (1988, 1989). This genus has some adult derived features (e.g. wingless, brachyelytrous) similar to those of the Mediterranean genus Berberomeloe Bologna, 1989; in common with this genus has also some characters of the first instar larva (Bologna and Pinto, 2001). We are inclined to consider these characters as indicative of relationships between these two genera. 
The genus Trichomeloe is phenetically similar to Meloe, but is easily distinguishable by the diffuse setation on the whole body (character present only in few subgenera of Meloe), the reniform pronotum (feature in common to some Meloe (Eurymel$o e)$ only), the presence of a more or less extended red spot on the head. In the subfamily Meloinae, as well as in Tetraonycinae and Nemognathinae, repeated phenomena of converging brachyelytry with or without associated wingless - evolved in several genera. Some species were originally referred to Meloe Linnaeus, 1758 and afterwards to the following genera: Berberomeloe Bologna, 1989, Lyttomeloe Denier, 1920, Parameloe Denier, 1933 (tribe Lyttini), Pseudomeloe Fairmaire and Germain, 1863 (tribe Pyrotini), Cordylospasta G. Horn, 1875, Megetra LeConte, 1859, Cysteodemus LeConte, 1851 (tribe Eupomphini), Pseudabris Fairmaire, 1894 (tribe Mylabrini), Physomeloe Reitter, 1911 Oreomeloe Tan, 1981 (tribe Meloini), Meloetyphlus Waterhouse, 1872 (tribe Tetraonycini), Allendesalazaria Martinez de la Escalera, 1910, Sitarobrachys Reitter, 1883 (tribe Nemognathini), etc.

An annotated catalogue of the species, and the description of two new species, namely $T$. mesopotamicus n.sp. and T. syriacus n. sp., are reported in Appendix I.

Keys to the species (for both males and females) are reported in Appendix II.

The examined material is preserved in the collections listed in Appendix III, with associated acronyms reported in the text.

\section{Discussion}

A cladistic classification of the genus Trichomeoe was not elaborated because one species was unavailable for the analysis (T. ovatus (Pripisnova, 1986)) and the number of recognized synapomorphies was scarce. In this paper we adopt a classification, primarily based on one autapomorphy detected in each group of species we identified: the structure of male antennomeres and the number of aedeagal hooks. In the first group of species (group of $T$. chrysocomus) we arranged two distinct species, while the second group (group of T. sericellus) includes six species belonging to two distinct subgroups. These groups are supported also by slight differences in larval morphology (see above). (a) Group of T. chrysocomus (Miller, 1861): includes two species, which are well distinct by several characters, particularly the pronotum shape: T. chrysocomus and T.conicicollis. Both the species of this section have, as synapomorphic condition, the aedeagus with a single apical hook; as simplesiomorphic condition, males have antennomeres cylindrical and lack a modified area on IV-VII (Figs 7b, 7d). In the subfamily Meloinae the presence of two ventral hooks on the aedeagus is the common condition. The reduction to a single hook is present, as convergence, in some genera or groups of species in several tribes: e.g. in three genera of Epicautini (namely Epicauta Redtenbacher, 1845, Denierella Kaszab, 1952, Psalydolytta Péringuey, 1909); in the species of some groups of Hycleus as the group of H. brunnipes (Klug, 1845) and in that of H. amoenus (Marseul, 1872), in a few Ceroctis Marseul, 1870 and Mylabris Fabricius, 1775 (Mylabrini); in Sybaris Stephens, 1832, a few Lytta Fabricius, 1775 and one Teratolytta Semenow, 1894 (Lyttini); in Somalarthrocera Turco and Bologna, 2008 (Cerocomini), etc.

(b) Group of T. sericellus (Reiche, 1857): includes six species, belonging to two distinct subgroups: subgroup A (T. deflexus, T. mesopotamicus, T. sericellus, T. syriacus); subgroup B (T. ottomanus, T. ovatus). The species of this group have, as synapomorphic condition, the male antennomeres with a raised, modified area, more or less visible on antennomeres IV-VII (Figs 7a, 7c). The presence of two aedeagal hooks is a simplesiomorphic condition. The subgroup A seems greatly homogenous, while the subgroup B is transitorily proposed, because one species is known to us only on the basis of the description; it appears characterized by the presence of glabrous oval spots on abdominal tergites. No similar antennal derived characters are described in other lyttine genera. Modifications on male antennomeres are very common in other genera of this and other tribes, but usually are represented by the enlargement or thickness of one or more antennomeres, or by an extremely dimorphic form (as in some Lydomorphus, Lytta, or the Cerocomini). A raised area, slightly similar to that of Trichomeloe antennomeres is present only in the genus Alosimus Mulsant, 1857, which belongs to a distinct lyttine lineage (Turco and Bologna, 2005). 


\section{Acknowledgements}

We thank all colleagues who collaborated in the field work: P. Audisio, M. Biondi, P. Bombi, E. Calvario, A. Casale, P. De Salvo, P. Giachino, C. Manicastri, C. Marangoni, B. Osella, P. Scaramozzino, A. Vigna Taglianti and M. Zapparoli. We are also grateful to the following entomologists for the loan of specimens or for the permission to examine their collections, listed in the Material and methods paragraph: M.E. Bacchus (previously at London), C. Besuchet (previously at Geneva), F. Cassola (Rome), M. Daccordi (Turin, previously at Verona), P. Giachino (Turin), C. Girard (Paris), M.A. Jäch (Vienna), Z.Kaszab (Budapest), S. Krejcik Unicov, Czech Republic), C. Leonardi (Milan), A. Liberto (Rome), J. Lückmann (Bensheim), O. Merkl (Budapest), B. Osella (L'Aquila, previously at Verona), T. Pavlicek (Haifa), J. Pinto (Waldport, Oregon; previously at Riverside), R. Poggi (Geneva), E. Ratti (Venice), J.-C. Ringenbach (Pau, France); J. Scheuern (Munich), A. Vigna Taglianti (Rome) and P. Weill (Pau, France),

\section{References}

Aksentjev SI. 1988. A catalogue of the genus group taxa of the beetle family Meloidae (Coleoptera). Entomologicheskoye Obozreniye 67: 569-582 [In Russian].

Baudi di Selve F. 1878. Coleotteri Eteromeri esistenti nelle collezioni del R. Museo zoologico di Torino ed in altre italiane. Atti della reale Accademia delle Scienze di Torino 13: 765-866, 1027-1183.

Bodenheimer FS. 1934. Studies on the Ecology of Palestinean Coleoptera: II. Seasonal and diurnal appearance and activity. Bulletin de la Société Royale d'Entomologie d'Egypte 18: 211-241.

Bologna MA. 1983. Utilizzazione dei dati biologici nella sistematica dei Meloidae (Coleoptera). Atti del XII Congresso Nazionale Italiano di Entomologia, Roma 1980. Roma 2: 21-36.

Bologna MA. 1986. Données faunistiques et zoogéographiques sur les Meloidae (Coleoptera) de Grèce. Biologia Gallo-hellenica 12: 409-419.

Bologna MA. 1988. Il popolamento delle aree di transizione zoogeografica: i Meloidae (Coleoptera) della regione siropalestinese. Biogeographia (n.s.) 12: 27-47.

Bologna MA. 1989. Berberomeloe, a new West Mediterranean genus of Lyttini for Meloe majalis Linné (Coleoptera, Meloidae). Systematics and bionomics. Bollettino di Zoologia 55 (1988): 359-366.

Bologna MA. 1991. Coleoptera Meloidae, Fauna d'Italia XXVIII. Bologna: Calderini.

Bologna MA, Aloisi G. 1992. Systematics of Lydomorphus Fairmaire 1882, with a description of the first instar larva of L. dusaulti (Coleoptera Meloidae). Tropical Zoology 5: 55-71.

Bologna MA. 1994. I Meloidae della Grecia (Coleoptera). Fragmenta Entomologica 25 (suppl.): 1-119.

Bologna MA. 1995. Meloidae. In: Angelini F, Audisio P, Bologna MA, De Biase A, Franciscolo ME, Nardi G, Ratti E,
Zampetti MF. 1995. Coleoptera Polyphaga XII (Heteromera escl. Lagriidae, Alleculidae, Tenebrionidae), 30 pp. In: Minelli A, Ruffo S, La Posta S (eds.). Checklist delle specie della fauna italiana, 57. Bologna: Calderini.

Bologna MA, Di Giulio A. 2002. Review of the genus Stenodera with a description of the first instar larva of $S$. puncticollis (Coleoptera: Meloidae). European Journal of Entomology 99: 299-313.

Bologna MA, Marangoni C. 1990. Dispersal, dispersion and phoresy in the blister beetles fauna (Coleoptera, Meloidae) of eastern Mediterranean and other islands. Accademia Nazionale dei Lincei, Atti dei convegni Lincei, "Biogeographical Aspects of insularity" 85: 345-366.

Bologna MA, Pinto JD. 2001. Phylogenetic studies of Meloidae (Coleoptera) with emphasis on the evolution of phoresy. Systematic Entomology 26: 33-72.

Bologna MA, Pinto JD. 2002. The Old World genera of Meloidae (Coleoptera): a key and synopsis. Journal of Natural History 36: 2013-2102.

Bologna MA, Oliverio M, Pitzalis M, Mariottini P. 2008. Phylogeny and evolutionary history of the blister beetles (Coleoptera, Meloidae). Molecular Phylogenetics and Evolution, 48: 679-693.

Borchmann F. 1917. Pars 69: Meloidae, Cephaloidae. In: Junk W, Schenkling S. Coleopterorum Catalogus. Berlin: Junk.

Chikatunov V. 1999. Catalogue of the beetles (Coleoptera) of Israel and adjacent areas. Tel Aviv: Department of Zoology, The George S. Wise Faculty of Life Sciences, Tel Aviv University.

Cros A. 1934. Le Meloe chrysocomus Miller; sa larve primaire. Bulletin de la Société Royale d'Entomologie d'Egypte 1934: 427-435.

Cros A. 1940. Essai de classification des Meloides algériens. Congreso Internacional de Entomologia VI, Madrid 1935: 312-338.

Escherich K. 1889. Nachträge und Berichtingungen zum catalogus Coleopterorum von Gemminger und Harold, betreffend die gattung Meloë. Deutsche Entomologische Zeitschrift 1889: 333-335.

Escherich K. 1890. Revision der behaarten Meloë-arten der alten Welt. Wiener Entomologische Zeitung 9: 87-96.

Fairmaire L. 1884. Coléoptères recueillis per M. L'abbé David à Akbès (Asie-Mineure) et descriptions des espèces nouvelles. Annales de la Société Entomologique de France 4: 165-180.

Finkel M, Chikatunov V, Nevo E. 2002. Coleoptera of "Evolution Canyon " II: Lower Nahal keziv, Western Upper Galilee, Israel. Sofia-Moscow: Pensoft.

García-París M. 1998. Revisión sistematica del género Berberomeloe (Coleoptera, Meloidae) y diagnosis de en endemismo iberico olvidado. Graellsia 54: 97-109.

Kaszab Z. 1958. Die Meloiden Afghanistans (Coleoptera). Acta zoologica Academiae Scientiarum Hungaricae 3: 245312.

Kaszab Z. 1961. Neue Meloiden (Coleoptera) aus dem Museum A. Koenig in Bonn. Bonner Zoologische Beiträge 12: 343-353.

Kaszab Z. 1968. Ergebnisse zoologischer Sammelreisen in der Türkei. Coleoptera: Meloidae. Annalen des Naturhistorischen Museums in Wien 72: 443-450. 
Kaszab Z. 1969. The system of the Meloidae (Coleoptera). Memorie della Società Entomologica Italiana 48: 241-248.

Katbeh-Bader A. 1996. Contribution to the knowledge of Meloidae of Jordan. Bollettino della Società Entomologica Italiana 128: 137-142.

Lawrence JF. 1991. Order Coleoptera. In: Stehr FW (ed.) Immature Insects. 2. Dubuque, Iowa: Kendall/Hunt, 144-298.

Luigioni P. 1929. I Coleotteri d'Italia. Catalogo sistematicotopografico-bibliografico. Memorie della Pontificia Accademia delle Scienze Nuovi Lincei (2) 13: 1-1159.

MacSwain JW. 1956. A classification of the first instar larvae of the Meloidae (Coleoptera). University of California Publications in Entomology 12: i-iv, 1-182.

Miller L. 1861. Neue Käfer aus Kindermanns Vorräthen beschrieben. Wiener Entomologische Monatsberichte 5: 169240, 2 pls.

Özbek H, Szaloki D. 1998. A contribution to the knowledge of the Meloidae (Coleoptera) fauna of Turkey along with new records. Turkish Journal of Zoology 22: 23-40.

Pardo Alcaide A. 1952. Los generos de Meloidae de la fauna hespérica. Graellsia 8 (1950): 39-79.

Pic M. 1900. Enumération d'Insectes Coléoptères recuillis en Orient en 1899. Miscellanea Entomologica 8: 85-86.

Porta A. 1934. Fauna Coleopterorum italica. IV. HeteromeraPhytophaga. Piacenza: Tip. Piacentino.

Pirspinova MG. 1987. Fauna and ecology of the meloid beetles (Coleoptera, Meloidae) of Tazhik SSR. Entomologicheskoye Obozreniye 6: 555-571 [In Russian].

Pliginskji V. 1911. Notice sur un caractère chez les representants du genre Meloë Linn. (Coleoptera, Meloidae). Revue russe d'Entomologie 11: 44-47.

Pliginskji V. 1914. Les Méloines (Coleoptera, Méloidae) de la collection de V. Motschulsky. Revue russe d'Entomologie 14: 254-261 [In Russian].

Reiche L, Saulcy F de. 1857. Espèces nouvelles ou peu connues de Coléoptères, recuillies par M. F. de Saulcy, mémbre de l'Institut, dans son voyage en Orient. Annales de la Société Entomologique de France 1857: 269-276.
Reitter E. 1889. Zwei neue Meloë-Arten aus Syrien und Armenien. Wiener Entomologische Zeitung 1889: 106-107.

Reitter E. 1895. Bestimmungs-tabelle der europäischen Coleopteren Meloidae. 1. Theil: Meloini. 32. Paskau: Verfassers.

Reitter E. 1907. Zwei neue Meloë aus der palaearktischen Fauna. Wiener Entomologische Zeitung 26: 214-215.

Reitter E. 1911. Fauna Germanica. Die Käfer des Deutschen Reiches, 3. Stuttgart: Lutz.

Sahlberg J. 1903. Coleoptera Levantina mensibus Februario et Martio 1896 in Palaestina et Aegypto inferiore collecta. Öfversigt Finska Vetenskaps Societet Föhrandlingen 45 (1902-1903) (18): 1-36.

Sahlberg J. 1913. Coleoptera Mediterranea Orientalia, quae in Aegypto, Palaestina, Syria, Caramania atque Anatolia occidentale anno 1904, collegerunt John Shalberg et Unius Sales. Öfversigt Finska Vetenskaps Societet Föhrandlingen 55 (1912-1913) (19): 1-282.

Schatzmayr A. 1941. Nuovi contributi alla conoscenza della Fauna delle Isole Italiane dell'Egeo. XIV. Cacce Coleotterologiche nel Dodecaneso. Bollettino del Laboratorio di Zoologia Generale e Agraria, Facoltà di Agraria, Portici 31: 342-368.

Selander RB. 1990. Blister beetles of the genus Pseudopyrota (Coleoptera: Meloidae). Journal of Kansas Entomological Society 63: 46-79.

Selander RB. 1991. On the nomenclature and classification of the Meloidae (Coleoptera). Insecta Mundi 5: 65-94.

Turco F, Bologna MA. 2005. Sexual and cleaning behaviour of Lydus trimaculatus Fabricius with remarks on the courtship of the Lyttini (Coleoptera: Meloidae). Deutsche Entomologische Zeitschrift 52: 131-137.

Received: 27 August 2008

Accepted: 16 November 2008

Published online: 22 December 2008 


\section{Appendix I. Annotated catalogue and descriptions of two new species}

For each species are indicated: the synonymies and the main citations from the literature; the type locality and the type material, also for synonyms; a short diagnosis and some taxonomical remarks; the list of localities with the acronym of collection and/or literature citations, divided in countries, and also provinces in the case of Turkey, the larger state. Two new species from the Iraki Mesopotamia and Syria respectively are also described.

Genus Trichomeloe Reitter, 1911

Meloë (Trichomeloë) Reitter, 1911: 391; Cros, 1934: 431

Trichomeloe, MacSwain, 1956: 71 (pars); Bologna, 1983: 24 (pars); Bologna, 1989: 359; Bologna, 1991: 109; Bologna and Pinto, 2002: 2055.

Type species: Meloe chrysocomus Miller, 1861: 206, by subsequent designation (MacSwain, 1956).

a) Group of Trichomeloe chysocomus

Trichomeloe chrysocomus (Miller, 1861) (Figs 6a, 8a)

Meloë chrysocomus Miller, 1861: 206; Escherich, 1890: 88, 94.

Meloë (Trichomeloe) chrysocomus, Reitter, 1911: 391. Trichomeloe chrysocomus, MacSwan, 1956: 71; Bologna, 1988: 30; Bologna, 1989: 359; Bologna, 1991: 110

Type material. Types of $T$. chrysocomus were not examined; they are probably preserved in the Motschulsky's collection, which is divided between the Moscow State University, the Zoological Museum of Saint Petersburg, the Humboldt Museum and the German Entomological Institute. The type locality is "Syrie" (Miller, 1861).

Diagnosis. Integument black, subopaque, with one small frontal red spot; setation dense both dorsally and ventrally, setae light golden-yellow, short, recumbent, longer on head, pronotum and elytra, producing a brownish shade to the body. Body length: 11.8-20 mm. Head subequal or scarcely wider than pronotum, eye small, slightly convex; templa 2.5 as long as the longitudinal diameter of eye, sub-parallel, slightly wider and rounded posteriorly; middle frontal line superficial; punctures fine, shallow, distanced, intermediate surface shagreened. Antennomeres elongate and subcylindrical; I elongate and widened at apex, II ca 0.5 as long as III subglobose, III-V progressively shorter, VI-X subequal and similar in length to V, XI twice as long as X, parallel and conically narrowed at apex; male segments III-VII unmodified. Pronotum reniform, almost twice as wide as long, sides anteriorly evidently curved; base depressed, middle surface longitudinally slightly depressed; punctures as on head. Elytra vaguely rugulose. Male genitalia (Fig. 6a): in dorsal view, gonocoxal piece short, slightly wide in the middle, gonostyli conically narrowed with stout apical lobes; in lateral view, gonostyli narrow, apical lobe evidently curved and stout, microsetose; aedeagus in lateral view with one single apical hook on ventral side, short and minute.
Remarks. Among numerous specimens from Hasanbeyli, southern Turkey, few of them have a darker setation, rather than light.

Distribution (Fig. 8a, triangle). CYPRUS: Cyprus (MRSN; Baudi, 1878; Cros, 1934; Bologna and Marangoni, 1990: 354).

TURKEY: (ADANA) Bahçe, Hasambeyli (CB). (HATAY) Akbès (HNHM as deflexus; JP; MNHN). (MARDIN) Akresta gecidi (CK). (ADYAMAN) Nemrut Daği (CSa). (SANLI URFA) near Halfeti, (CB); 15 km S Hilvan (CB).

SYRIA: Syria (HNHM; MNHN; NHMW; Miller, 1861; Baudi, 1878; Escherich, 1890; Reitter, 1895; Pliginskji, 1914; Cros, 1934; Chikutanov, 1999); Halep (CB; JP; HNHM; MHNG; MNHN); Halep, Tal Hadia (HNHM); Tell Halaf, Guzana, Djirdjibufer steppe (MNHU); 48 Km NW Hama, Ruins of Afamiya (Afamea) (CB); Jeirud (CW).

ISRAEL and PALESTINE: Israel (Chikutanov, 1999); Palestine (Cros, 1934); Jerusalem (MSNV; MCSN; MNHN; Pic, 1900); near Jerusalem, Chan Hatrura (Shalberg, 1913); Nazreth (Sahlberg, 1913); Kana (Sahlberg, 1913); Jordan River (Sahlberg, 1913); Guesthouse between Garimherzig and Samariter (MNHU). Uncertain localities: Moab or Moag or O'Megib? (MNHN); Lenal ? (HNHM). Chikatunov (1999) cited the species from the following areas: Upper Galilee, Valley of Yzre'el, Judean Hills, southern coastal plain, Dead Sea, northern Negev, central Negev. An undetermined species of Trichomeloe, possibly referable to this species, is cited by Finkel et al. (2002) from the Lower nahal Keziv, in the Western Upper Galilee, Israel.

JORDAN: Kerak, Wadi Al Hasa (CB).

Trichomeloe conicicollis (Reitter, 1907) (Figs 5a, 5c, 6b, 8a)

Meloë conicicollis Reitter, 1907: 215; Kaszab, 1968: 447.

Meloë (Trichomeloe) conicicollis, Reitter, 1911: 391.

Trichomeloe conicicollis, Bologna, 1988: 30; Bologna, 1989: 359; Bologna, 1991: 110.

Type material. In the HNHM is preserved the holotype, we examined, labelled "Monotypus 1907 Meloe conicollis Reitter" (white, with red frame, not orginal), "collez. Reitter", "Adana" (handwritten, white) (see Reitter, 1907).

Diagnosis. Integument shiny black with one small frontal red spot; setation sparse dorsally and denser ventrally, setae dorsally black-greysh and ventrally brownish, recumbent, short particularly on head, pronotum and elytra. Body length: 11.9-16 mm. of body. Head elongate, posteriorly obtusely subtrapezoidal, scarcely wider than pronotum, eye wide, convex; templa about 2.5 as long as the longitudinal diameter of eye, parallel, posteriorly elongate and converging on the occiput which appears almost potruded; middle frontal line superficial or well visible; punctures uniformly wide, deep and relatively dense, intermediate surface shagreened. Antennomeres (Fig. 5a) elongate and subcylindrical; I elongate and widened at apex, II slightly less than 0.5 than III, subglobose, III about 1.5 as long as the followings, IV-X subequal 

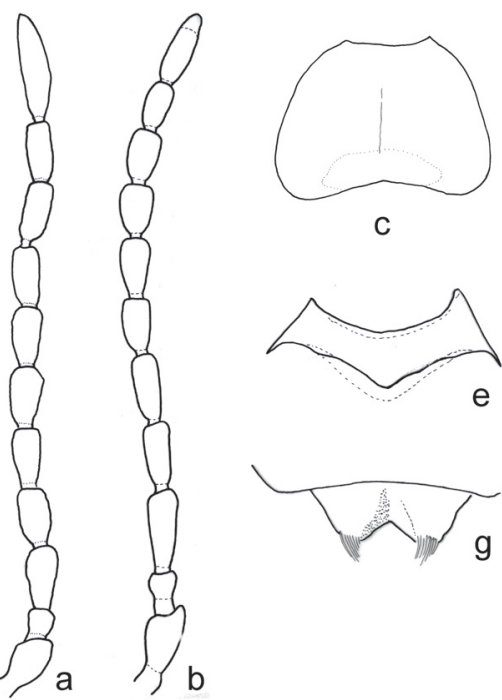

C
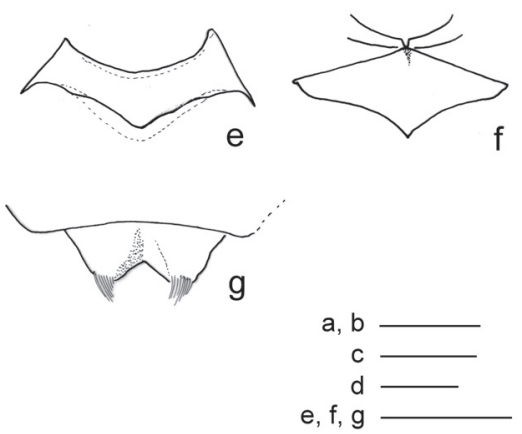

Fig. 5. Trichomeloe conicicollis, male: a) left antenna, dorsal view; c) pronotum. T. sericellus, male: b) left antenna, dorsal view; d) pronotum. T. deflexus, male: e) prosternum; f) mesosternum; g) last visible abdominal sternite. Scale bars $=1$ $\mathrm{mm}$.

Fig. 6. Male genitalia in ventral and lateral view and aedeagus in lateral view of: a) Trichomeloe chrysocomus; b) T. conicicollis; c) T. deflexus; d) T. syriacus; e) T. mesopotamicus; f) T. sericellus; g) T. ottomanus. Scale bars $=1 \mathrm{~mm}$. and similar in length, $\mathrm{XI}$ about twice as long as $\mathrm{X}$, parallel and conically narrowed at apex; male segments III-VII unmodified. Pronotum (Fig. 5c) elongate subcampaniform, at base narrower than elytra, wider than long at base, sides progressively oblique and anteriorly curved; base depressed, middle surface longitudinally slightly depressed, sides vaguely depressed; punctures as on head, but in some specimens rugosities are also present, particularly at base. Elytra with longitudinal, superficial rugosities. Protarsi and mesotarsi of male very short. Abdominal tergites deeply punctured. Male genitalia (Fig. 6b): in dorsal view, gonocoxal piece quite elongate, gonostyli setose and slightly depressed at base, conically narrowed with slender apical lobes, with long setae on both sides; in lateral view, gonostyli very narrow and slender, progressively producing in an apical lobe, slightly curved and with elongate setae; aedeagus in lateral view with one single apical hook on ventral side, short and minute, oblique and acute.

Remarks. This species differs greatly from others by the shape of occiput, pronotum, and the elytral rugosities. Also the shape of male genitalia greatly distinguish $T$. conicicollis from all other species, T. chrysocomus included.

Distribution (Fig. 8a, square). GREECE: Dodekanissa, Castelorizo Island (MSNM; MSNV; Schatzmayr, 1941; Bologna, 1986; Bologna and Marangoni, 1990: 353; Bologna, 1994: 10).

TURKEY: (MUĞLA) (CB); Fethye, Dodurga (NHMW; Kaszab, 1968). (ANTALYA) Lycian Taurus (HNHM; MNHU; MZUA); Kaş (CB; MRSN). (ADANA) Adana (HNHM; Reitter, 1907). Other specimens with no detailed localities (HNHM; NHMW).
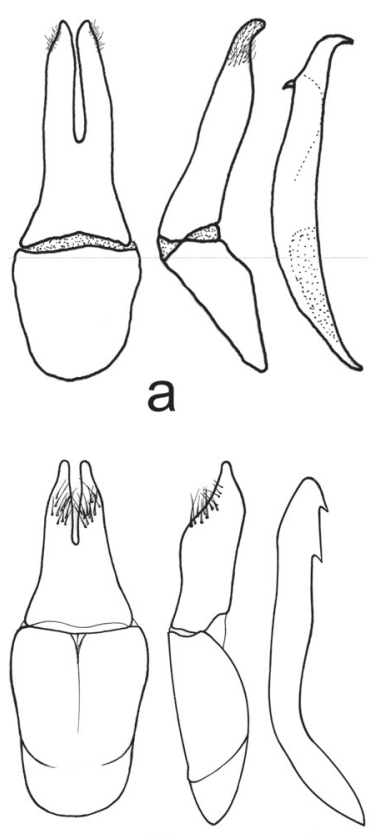

e
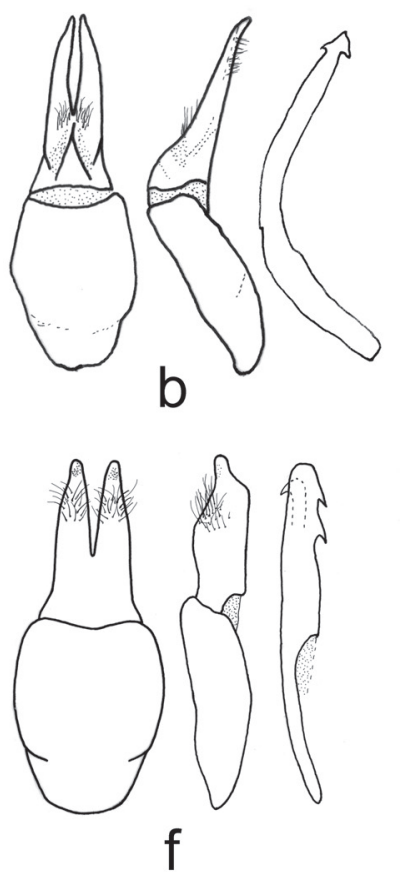
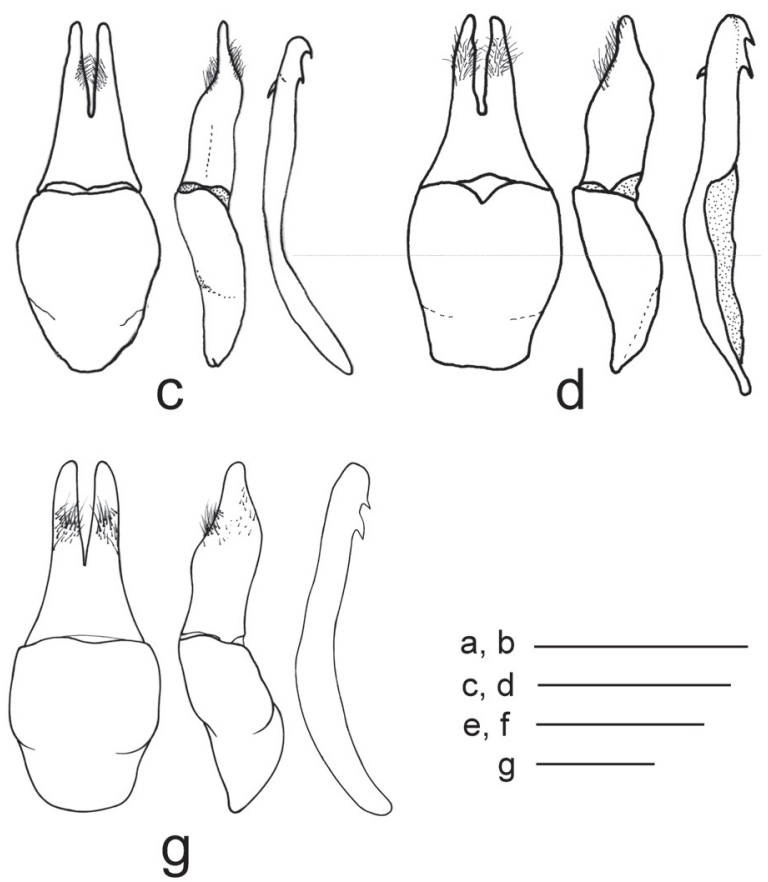


\section{(b) Group of Trichomeloe sericellus}

Subgroup A

Trichomeloe deflexus (Reitter, 1889) (Figs 5e-5g, 6c, 8b)

Meloë deflexus Reitter, 1889: 106; Escherich, 1890: 88, 95; Reitter, 1895: 13.

Meloë (Trichomeloe) deflexus, Reitter, 1911: 391.

Trichomeloe deflexus: Bologna, 1988: 30; Bologna, 1989: 359; Bologna, 1991: 110.

Type material. Reitter (1889) indicated "Syrien" as Type locality, but this must be actually restricted to "Jerusalem". In fact, in the HNHM are preserved the following specimens we examined: holotype, labelled " Meloe deflexus Reitter"(white, red framed), "coll. Reitter" (red on white), "Jerusalem" (printed, white), "U. Sahlb." (printed, white); 1 paratype male, with the same labels of the holotype; 1 paratype male, with similar labels, actually belongs to $T$. sericellus.

Diagnosis. Integument leaden black, subopaque, with one small red frontal spot widened anteriorly, subtriangular or oval; setation short, quite dense both dorsally and ventrally, setae light yellow-grey, short, longer on head and pronotum where it is recumbent along the depressions. Body length: 10$18.6 \mathrm{~mm}$. Head subequal or scarcely wider than pronotum, eye small and convex, in lateral view fore margin slightly incised, short and only slightly narrowed anteriorly; templa 2.5 as long as the longitudinal diameter of eye, sub-parallel, slightly wider and rounded posteriorly; middle frontal line superficial; punctures on head and pronotum deep and denser, intermediate surface shagreened. Antennomeres elongate and subcylindrical; I elongate and widened at apex, II ca 0.5 as long as III subglobose, III antennomere as long as IV; VI-X subequal and similar in length to V, XI twice as long as $\mathrm{X}$, parallel and conically narrowed at apex; male segments III-VII modified to form an anterior almost impunctate, shagreened area, extended also dorsally, III-VI in lateral vision not distinctly widened at apex. Pronotum subreniform, almost twice as wide as long, sides laterally parallel and anteriorly slightly curved; base depressed, middle surface longitudinally slightly depressed; punctures as on head. Elytra obsolescently rugulose. Male genitalia (Fig. 6c): in dorsal view, gonocoxal piece short, wide in the middle, gonostyli conically narrowed with stout apical lobes; in lateral view, gonostyli narrow, apical lobe slender, elongate, with long setae on both sides; aedeagus in lateral view with two apical hooks on ventral side, both short, the proximal one minute.

Distribution (Fig. 8b, spot). TURKEY: (ADIYAMAN) Narince (Özbek and Szaloki, 1998); Karababa bridge (Özbek and Szaloki, 1998). (HATAY) Tapbogazi, Issuspass, Amanus (Kaszab, 1968; Özbek and Szaloki, 1998); Akbès (MNHN). (GAZIANTEP) Sakcagöz (NHMW; Kaszab, 1968); Yavuzeli NW of Gaziantep (NHMW, Kaszab, 1968); (KAHRAMAN MARAS) Pazarcik (MSNV).

SYRIA: Syria (HNHM; MNHN; NHMW; Reitter, 1889; 1895; Escherich, 1889; 1890 Özbek and Szaloki, 1998 ); Damaskus (HNHM; MNHN); Basalt Rock 6 km N of Sal- haa (HNHM); Ganawat (CW); Es Suweida (CW).

ISRAEL and PALESTINE: Palestine (HNHM); Jaffa (NHMW); Nablous (MNHN); Jerusalem (BMNH; HNHM; JP; MCSN; MNHN; MSNV; MSNM; NHMW; Sahlberg, 1913); Jerusalem Mt. Sion (MNHN); Jerusalem, Mount of Olives (Sahlberg, 1903); between Jericho and Jerusalem (MNHU); Ghor (MNHN); Jordan Valley, S Mehola, Wadi Malih (CB; SMNS); Bethlem Eastern side (HNHM); Maale, Adumim (CB); Emek Isaac (HNHM); Beer Sheba (CB); Beer Sheba near Tümpel (NHMW); NE Beer Sheba (CB; NHMW).

JORDAN: Jerash (CB); Zerka (MHNG); E Jordan, Wadi Schaib (MHNG); E Jordan, Fuhes (MHNG); S Jordan, Wadi Waba S Makba (HNHM); S Jordan, Madaba (MHNG); S Jordan, Wadi Wala, S Madaba (MHNG); Abu

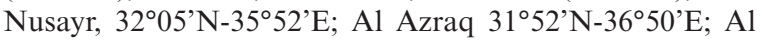
Jubayhah $32^{\circ} 01^{\prime} \mathrm{N}-35^{\circ} 52^{\prime} \mathrm{E}$; Al Karak $31^{\circ} 11^{\prime} \mathrm{N}-35^{\circ} 42^{\prime} \mathrm{E}$; Al Kufrayn $31^{\circ} 50^{\prime} \mathrm{N}-35^{\circ} 55^{\prime} \mathrm{E}$; Al Muqabalayn $31^{\circ} 54^{\prime} \mathrm{N}-$ $35^{\circ} 54^{\prime} \mathrm{E}$; Amman $31^{\circ} 57^{\prime} \mathrm{N}-35^{\circ} 56^{\prime} \mathrm{E}$; As Salt $32^{\circ} 03^{\prime} \mathrm{N}-$

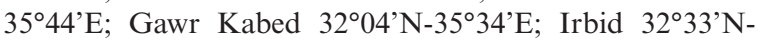
$35^{\circ} 51^{\prime} \mathrm{E}$; Khilda $32^{\circ} 00^{\prime} \mathrm{N}-35^{\circ} 51^{\prime} \mathrm{E}$; Na'ur $31^{\circ} 53^{\prime} \mathrm{N}-35^{\circ} 50^{\prime} \mathrm{E}$; Sahab $31^{\circ} 53^{\prime} \mathrm{N}-36^{\circ} 00^{\prime} \mathrm{E}$; Suwaylih $32^{\circ} 02^{\prime} \mathrm{N}-35^{\circ} 50^{\prime} \mathrm{E}$; Tabar-

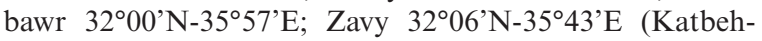
Bader, 1996: some of these records could refer to other species).

\section{Trichomeloe mesopotamicus Bologna n. sp. (Figs 6e, 8b)}

Type material. 1 male holotype and 2 males and 2 females paratypes, "Mesopotamia Mosul" (MNHU, identified as chrysocomus, $1 \mathrm{CB}$ ); 1 male paratype, "Mesopotam. Assur, 08"; (NHMW, identified as "chrysocomus Dr. Z. Kaszab, 1959"); 2 females paratypes, "Mesopotamia Mosul, coll. Hauser v.09" (NHMW); 1 male paratype, "Assur Mesopotam. Pietschmann .10"; "Mesopotam. Esp. Nat. Ö.V. 1910"; chrysocomus Miller det. Breit" (NHMW); 1 female paratype "Mesopot. Assur 08"; (NHMW, identified as "Meloe deflexus Dr. Z. Kaszab 1959"); 1 male paratype, "Mesopotamia Mossul coll. Hauser 5.09" (NHMW); 1 female paratype, "Assur Mesopotam. Pietschmann .10"; "Mesopotam. Esp. Nat. Ö.V. 1910" (NHMW).

The type locality, Mosul, is located in the Northern Irak; the locality of Assur is located on the right side of the Tigris River, about $110 \mathrm{~km}$ South of Mosul.

One male paratype (CB), lacks V-XI right antennomeres, and another male paratype (NHMW) lacks right metatarsomeres III-IV.

Other specimens examined: 1 male Mosul (HNHM), 1 male Assur (IV.1908 HNHM).

Description. Integument black, opaque, with one small transverse frontal red spot; setation very dense both dorsally and ventrally, setae light golden-yellow, producing a brownish shade to the body, elongate on the whole body, on the pronotum slightly recumbent along the depressions, slightly shorter on elytra and ventrally. Body length: 10-16.2 mm.

Head subequal or scarcely wider than pronotum, eye dorsally only slightly convex, in lateral view fore margin incised, narrowed anteriorly; templa 2.5 as long as the longitudinal 
diameter of eye, subparallel, slightly wider and rounded posteriorly; middle frontal line superficial; punctures on head and pronotum slightly deep and distanced, intermediate surface almost umpunctured. Antennomeres elongate and subcylindrical; I elongate and widened at apex, II ca 0.5 as long as III, subglobose, III shorter than IV, VI-X subequal and similar in length to V, XI twice as long as X, parallel and conically narrowed at apex; male segments III-VII modified to form a wide anterior almost impunctate, shagreened area, slightly narrower on VII.

Pronotum subreniform, almost twice as wide as long, sides more obliquely narrowed anteriorly where are slightly curved; base depressed, middle surface longitudinally depressed; punctures as on head. Elytra vaguely rugulose.

Male genitalia (Fig. 6e): in dorsal view, gonocoxal piece slightly elongate, wider anteriorly, gonostyli quite short and with stout apical lobes; in lateral view, gonocoxal piece narrow and elongate, gonostyli subcylindrical on the basal third, then dorsally curved in the middle and suddenly inclined to form a short apical lobe, with very long dorsal setae on the apical third, almost straight on ventral margin; aedeagus in lateral view with two apical hooks on ventral side, both short.

Remarks. This species is phenetically very similar to T. chrysocomus based on integument and setation colour, and the pronotum shape; some paratypes were previously identified as chrysocomus by the late specialist Dr. Z. Kaszab. It actually belongs to another group of species, based on the modified male antennae consisting of a distinct raised, nude and smooth area on segments III-VII, and the aedeagus with two hooks.

Among the group of species related to T. sericellus, $T$. mesopotamicus appears more similar to $T$. deflexus because of the slender antennomeres, head colouration, and the subdepressed pronotum. The main differences characterizing $T$. mesopotamicus vs. T. deflexus include: integument blackbrown more subopaque; red frontal spot transverse vs. elongate in front; setation rufescent, longer and denser vs. almost grey, slightly shorter and sparser; head and pronotum punctures more superficial and distanced, intermediate surface almost smooth vs shagreened; eye in lateral view semilunar and more narrowed to the maxillary base and not rectilinear on frontal side, shorter to the maxilla base, on dorsal view less convex; antennomere III on dorsal view shorter than IV and slightly widened anteriorly vs. parallel; modified area on antennomeres III-VII more raised, particularly on III; pronotum sides more obliquely narrowed in front vs. more parallel.

Distribution (Fig. 8b, triangle). IRAK: Mosul; Assur (see above).

Trichomeloe sericellus (Reiche and Saulcy, 1857) (Figs 1, 5b$5 \mathrm{~d}, 6 \mathrm{f}, 7 \mathrm{a}, 7 \mathrm{c}, 8 \mathrm{c})$

Meloë sericellus Reiche and Saulcy, 1857: 273, tav. 5, fig 12: Escherich, 1890: 88, 94; Reitter, 1895: 13; Jeannel and Paulian, 1944: 80, fig 28.

Meloë (Trichomeloe) sericellus, Reitter, 1911: 391; Porta, 1934: 38 .
Meloë (Trichomeloe) sericellus ab. ocularis Kaszab, 1961: 531.

Trichomeloe sericellus, Bologna, 1988: 359; Bologna, 1989: 359; Bologna, 1991: 110.

Types. Reiche and Saulcy (1857) cited "Nablouse" et "Nazareth" as Type locality. Actually, we examined at the MNHN (box of "Types") the holotype, labelled "Meloe sericellus Reiche Nazareth" (white, handwritten), "121 57"(white, round). Close to the holotype are positioned two additional specimens, we considered as paratypes, each only with a white, round label, respectively with the indication " $12157^{\text {" }}$ and "288 39".

Diagnosis. Integument black, subopaque, head more or less extensively red, the red colouration usually is not extended on the anterior part of the frons and posteriorly to eye, laterally and ventrally and on the most part of templa; setation light yellow, dense and diffuse, short, recumbent, longer on frons, labrum and pronotum. Body length: 12.1-24 mm. Head distinctly wider than pronotum, eye small, scarcely convex, fore margin not evidently incised, anteriorly narrowed; templa 2.5 as long as the longitudinal diameter of eye, rounded, slightly wider on the middle, posteriorly very rounded; frons wide and flat, middle line almost superficial; punctures slightly deep, distanced, superficial on frons and occiput, intermediate surface shagreened. Antennomeres (Figs 5b, 7a, 7c), elongate and subcylindrical; I elongate and widened at apex, II 0.5 as long as III subglobose, III-V progressively shorter, VI-X subequal and slightly shorter than V, $\mathrm{XI}$ two times as long as $\mathrm{X}$, parallel and conically narrowed at apex; male segments III-VII modified to form an anterior almost impunctate, shagreened area, not extended dorsally, III-VI in lateral vision evidently widened at apex. Pronotum (Figs 1, 5d) reniform, wider than long, widened in basal third and anteriorly evidently narrowed, sides rounded; base depressed and longitudinally slightly depressed in the middle; puncturation as on head; elytra vaguely rugulose. Male genitalia (Fig. 6f): in dorsal view, gonocoxal piece wide in the middle and gonostyli conically narrowed with stout apical lobes; in lateral view, gonocoxal piece wide and short, gonostyli subcylindrical on the basal third or more on ventral margin, then inclined and forming a short apical lobe; aedeagus in lateral view with two apical hooks on ventral side, similarly inclined, the prossimal one longer; endophallus hook curved.

Remarks. Kaszab (1961) described from Sicily (see below) and Crimea, the intraspecific form ocularis, characterized by the extreme extension of the red colouration on the head. According to the Zoological Nomenclature rules, this name, described after 1960, is not available. Actually the red colouration is variable, even if usually is very extended: for example, about $80 \%$ of 13 specimens from Golan we examined, has only a semilunar red macula.

$T$. sericellus seems strictly related to $T$. deflexus and $T$. syriacus n.sp., based on pronotum and male genitalia shape; it differs from both species by the more extended red colouration of head, and the antennomeres IV-VII shorter than III, middle antennomeres more robust and widened anteri- 

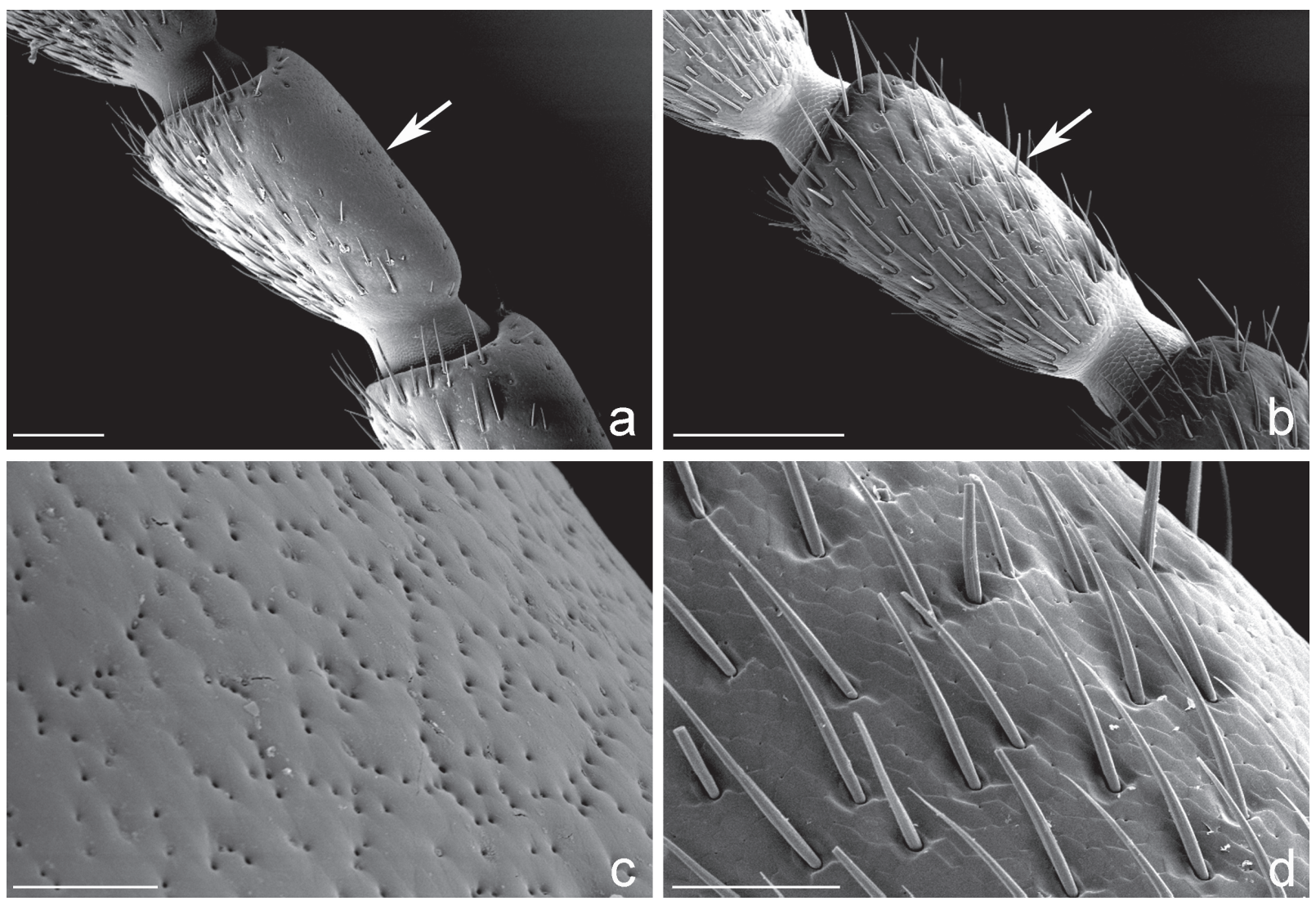

Fig. 7. Trichomeloe sericellus, antennomere III: a) dorsal view (the arrow indicates the modified area on anterior margin); c) detail of modified area. Trichomeloe chrysocomus, antennomere III: b) dorsal view; c) detail of anterior margin. Scale bars: $\mathrm{a}-\mathrm{b}=200$ $\mu \mathrm{m} ; \mathrm{c}=20 \mu \mathrm{m} ; \mathrm{d}=50 \mu \mathrm{m}$.

orly; from $T$. deflexus it differs also by the parameres more robust, a character in common with $T$. syriacus.

Distribution (Fig. 8c, spot). TURKEY: Turkey (Chikutanov, 1999). (HATAY) Akbès (MNHN; Fairmaire, 1884).

SYRIA: Syria (CB; HNHM; MCSN; MHNG; MNHN; MNHU; MRT; MZR; Reiche, 1857; Baudi, 1878; Escherich, 1890b; Reitter, 1895; Pliginskji, 1911; 1914; Kaszab, 1961; Chikutanov, 1999); Golan (NHMW); Golan near El Qunetra 3309'45"N 3557'30"E (CB; NHMW); Krak des Chevaliers, W Homs (HNHM); Saasa (BMNH).

LEBANON: Lebanon (MNHN, MNHU); Beyrouth (MNHN); Sydon (MNHN); Ain El Zait $6 \mathrm{~km} \mathrm{E} \mathrm{of} \mathrm{El} \mathrm{Lail}$ (CALC); Baruk (Sahlberg, 1913).

ISRAEL and PALESTINE: Palestine (CB; HNHM; MCSN; MNHN; MNHU; Baudi, 1878; Pliginskji, 1914). Khermon-Ridge Har, Khavushit N Majdal e-Sharms (CL; CSt); Jaffa (HNHM; MNHN; NHMW); Mt. Carmel (MNHN); Haifa (HNHM, MNHN); Tel Aviv (CB); Lake Tiberias, Genezareth (Sahlberg, 1913); Tel Aviv, Ben Shemen (CB; MZUR); Galilaea (MNHU); Galilaea, Mt. Meron (CB); Galilaea, Mt. Meron, Ya'ar'am (CL; CSt); Nazrath (MCSN; MNHN; SMNS; Reiche and Saulcy, 1857; Kaszab,
1961); Ain Zabassim (MUH); Nablous (Reiche and Saulcy, 1857; Borchmann, 1917); Bethlem (MNHN); Jerusalem (MHNG; HNHM; MSNM; MSNV; MNHN; MNHU; Sahlberg, 1913); Kiryat Anavim (Bodenheimer, 1934); Kubbet Râhil (Sahlberg, 1903); Der Aban (Sahlberg, 1913); near Birel Maksur (CL; CSt); West Bank, Jerusalem (HNHM; MHNG); Negev, South of Sede Boqer (CL; CSt). Chikatunov (1999) cited the species from the following areas: Upper Galilee, Lower Galilee, Golan Heinghts, Mount Hermon, Samaria, Valley of Yzre'el, Judean Hills, Dead Sea, central coastal plain, northern Negev.

Uncertain locality: Sarvid (JP).

Some uncertain records were quoted in the literature. In particular, this species was cited from Palermo (Luigioni, 1929; see also Bologna, 1991) and generically from Sicily (Porta, 1934; Kaszab, 1961; see also Bologna, 1991, 1995). At the HNHM is preserved one specimen (paratype of the invalid form ocularis), we examined, labelled "Sicilia" and studied by Kaszab (1961). The citation from Naples (as "Napoletano": Luigioni, 1929, or as "Campania": Porta, 1934), could derive from an error made by Borchman (1917), who indicated "Neapel", as misinterpretation of "Nablous", a Palestinian town. Alternately, if the presence in Sicily is 
confirmed, the Luigioni's citation could indicate the old name of the Naples Kingdom, which included Sicily until 1861. Kaszab (1961), on the base of one specimen (paratype of the unvalid form ocularis) quoted $T$. sericellus also from Crimea (southern Ukraina).

The species, as the most part of the genus, seems to be endemic to the Levant and Middle East, and both the eccentric records (Sicily and Ukraina) seem to be rejected.

\section{Trichomeloe syriacus Bologna n. sp. (Figs 6d, 8a)}

Type material. 1 male holotype from "Sy. Tadmur, 15.iii.1980, Gräber von Palmyra, R. Kinzelbach leg." (CB). 1 female paratype from "Syria, Palmyra, 30.i.1989, P. De Salvo leg." (CB). 1 male and 1 female paratypes from "Syrie, Rankous, 08.iii.02, P. Weill" (CB and CW).

One female paratype has antennomeres slightly damaged.

Other specimens examined. 1 specimen from Palmyra, found dead and very damaged (without appendices), was not considered as paratype. Other specimens from Palmyra, previously identified as $T$. deflexus, are preserved at SMNS, but were not re-examined during this revision.

Description. Integument shiny black, with one small red and suboval frontal spot; setation very short and black, sparse on head, pronotum and elytra, ventrally light grey longer and quite dense. Body length: 14.0-22.1 mm.

Head wider than pronotum, eye small and convex, in lateral view fore margin slightly incised, short and slightly narrowed anteriorly; templa 2.5 as long as the longitudinal diameter of eye, sub-parallel, slightly wider and rounded posteriorly; middle frontal line superficial, but well visible; punctures deep but spaced, intermediate surface shagreened. Antennomeres robust, elongate and subcylindrical; I elongate and widened at apex, II ca 0.5 as long as III subglobose, III antennomere slightly shorter or subequal to IV; VI-X subequal and similar in length to $\mathrm{V}$, XI twice as long as X, parallel and conically narrowed at apex; male segments III-VII modified to form an anterior almost impunctate, shagreened area, slightly extended also dorsally, III-VI in lateral vision not distinctly widened at apex. Clypeus short and transverse; labrum transverse, short, emarginate anteriorly; both with puntures similarly than on head capsule.

Pronotum short, subreniform, more than twice as wide as long, sides subrounded from base; base evidently depressed, sides dorsally evidently convex (as in some species of the Meloe brevicollis complex); middle surface longitudinally slightly depressed; punctures and surface as on head, but slightly denser. Prosternum short and sub-transverse. Elytra vaguely rugulose, sub-alutaceous. Legs robust, with robust black setae.

Abdominal tergites with fine and scattered punctures and quite sparse setae; posterior margin of both last male tergite and sternite with long setae. Male genitalia (Fig. 6d): in dorsal view, gonocoxal piece short, wide in the middle, gonostyli robust, conically narrowed with robust and stout apical lobes; in lateral view, gonostyli robust, apical lobes elongate but robust, with long setae on both sides; aedeagus in lateral view with two apical hooks on ventral side, both short, the prossimal one great and apical in position.

Remarks. Among the species related to T. sericellus, this new species seems close particularly to $T$. sericellus and $T$. deflexus because it lacks modified body setation and the integument colour. It differs from $T$. sericellus, which has similar male gonostyli, by the reduced red frontal colouration, the shape of male middle antennomeres not widened apically, the shape of eye. Before this revision some specimens of the new species were identified as $T$. deflexus also by one of us (M.A.B.). Actually $T$. syriacus differs from $T$. deflexus because the head and pronotum setae black, shorter and more robust, as well as by the parameres more robust, particularly the apical lobes, and the shape of aedeagal hooks, which are more apical in position. Escherich (1890) consider as T. sericellus one variety with small red colouration, which could correspond to T. syriacus.

Distribution (Fig. 8a, spot). SYRIA: Palmyra; Rankous (see above)

\section{Subgroup B}

Trichomeloe ottomanus (Pliginskji, 1914) (Figs 6g, 8c)

Meloë ottomana Pliginskji, 1914: 254.

Meloë (Trichomeloe) frivaldszky [sic] Kaszab, 1958: 304.

Trichomeloe ottomanus, Bologna, 1988: 30; Bologna, 1989: 359; Bologna, 1991: 110.

Type material. Types of this species are preserved in the Motschulsky's collection, probably at the Moscow Museum. The type locality of the species is "Armain" (Pliginskji, 1914), a late name indicating most of the eastern Turkey and the Armenia Republic.

The holotype and 1 paratype of the synonym frivaldzky from South-East Turkey (Elazig), we examined, are preserved at the HNHM.

Diagnosis. Integument shiny black, but head reddish, except clypeus, in some specimens a small frontal spot, a short oval spot extended from the posterior margin of eye, the ventral side black; pronotum vaguely brownish on sides; setation light yellow, dense and diffuse, short, recumbent, longer on frons, labrum and pronotum; pronotum and abdomen with elongate light setae, distributed on tufts on abdomen, separated by nude areas. Body length: 11-22 mm. Head with a short and shallow depression posteriorly to eye, evidently wider than pronotum; eye small, scarcely convex; templa more than 2.5 as long as the longitudinal diameter of eye, wider on the middle, posteriorly rounded; frons wide and slightly convex, middle line almost superficial; punctures wide, deep, distanced, intermediate surface shagreened, frons medially almost unpunctate. Mandibles dorsally depressed, wide. Antennomeres, elongate and subcylindrical; I not evidently elongate, II 0.5 as long as III subglobose, III as long as V and slightly longer than IV, VI-X subequal and slightly shorter than V, XI two times as long as $\mathrm{X}$, parallel and conically narrowed at apex; male segments III-VII modified to form an anterior almost impunctate, shagreened area, slightly extended dorsally. Pronotum 


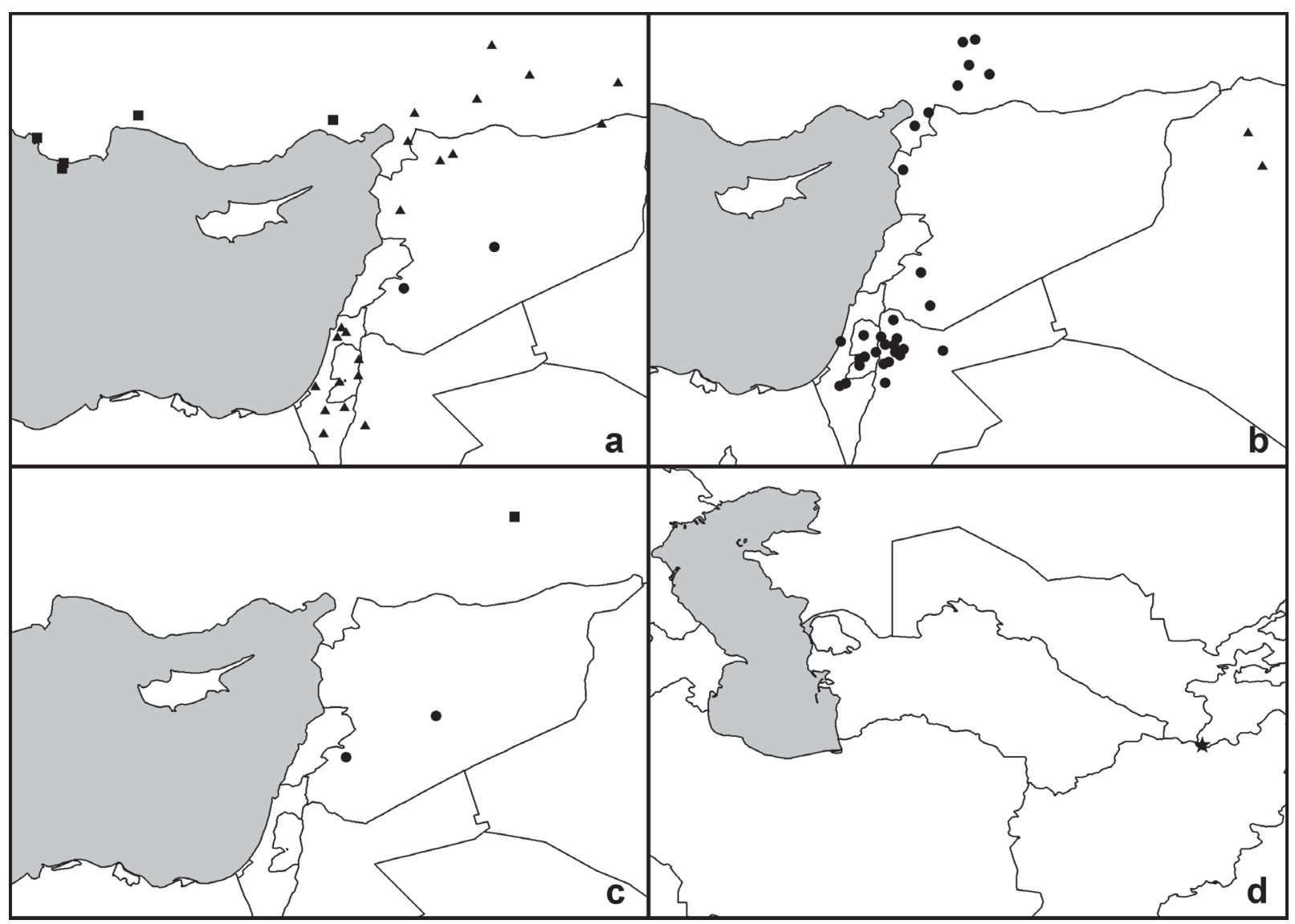

Fig. 8. Distribution of the species of the genus Trichomeloe: (a) T. conicicollis, square; T. chyrsocomus, triangle; T. syriacus, spot; (b) T. deflexus, spot; T. mesopotamicus, triangle; (c) T. sericellus, spot; T. ottomanus, square; (d) T. ovatus, star.

subpentagonal with smooth and nude raised areas on sides and longitudinally in the middle; base depressed and longitudinally evidently and largely depressed in the middle; puncturation as on head; elytra densely and finely rugulose, subopaque. Abdominal tergites densely setose but with shiny glabrous spots on sides and longitudinally in the middle; sternites III-V with anterolateral unsetated spotted surface. Male genitalia (Fig. 6g): in dorsal view, gonocoxal piece wide in fore half and gonostyli conically narrowed with wide and stout apical lobes; in lateral view, gonocoxal piece wide and short, gonostyli subcylindrical on the basal third or curved dorsally in the middle, then inclined to form a short and very stout apical lobe; aedeagus in lateral view with two apical hooks on ventral side, similarly inclined, the proximal one longer.

Remarks. This species differs considerably phenetically from others of the genus Trichomeloe because of the head punctures and colouration, mandible shape, the less reniform pronotum and anteriorly more angulate, medially depressed with raised nude areas, the abdomen densely setose. Interestingly, it shows several convergences in the integumentary structure with Meloe (Lasiomeloe) olivieri Chevrolat, 1833, endemic to Turkey.
Distribution (Fig. 8c, square). TURKEY: Anatolia (Kaszab, 1958). Armenia (Pliginskji, 1914). (ELAZIG) Elazig (HNHM).

SYRIA: Syria (JP; MNHN). Possibly this indefinite locality indicates late regions of the Ottoman Empire, now in southern Turkey.

Some specimens without locality label were also examined (CB; MNHN).

\section{Trichomeloe ovatus (Pripisnova, 1987) (Figs 8d)}

Meloë (Trichomeloe) ovatus Ppipisnova 1987: 43.

Trichomeloe ovatus, Bologna and Pinto, 2002: 2055.

Type material. According to the description, the male holotype, is preserved in the Tajikistan Academy of Sciences, and 1 male paratype at the San Petersberg Museum. We requested several times these specimens for study, but we did not obtain answer from the first institution, and the paratype was not found by the Curator in the second Museum.

The Type locality, Tigrovaja balka, is a Natural Reserve in the Amudarja region, about $180 \mathrm{~km} \mathrm{~S}$ of Dushambe, close to the border with Afghanistan, characterized by different 
ecosystems, from desert to forest and marshes. This species probably was collected in semidesert or steppe habitats.

Diagnosis (from the description). Body leaden black, shiny; setation light yellow, dense and diffuse, short, recumbent, disposed almost on tufts on head sides, uniformly and densely distributed on pronotum and elytra; abdomen with light setae, spaced out by nude areas. Body length 7-10 mm. Head subquadrate, frons convex, with a middle longitudinal line and two small projections overlooking the clypeus, base evidently emarginated at base; eye convex; punctures wide, subrugose on frons. Antennomeres elongate and subcylindrical, I-IV shiny, V-XI opaque. Pronotum slightly wider than head, subtrapeizoidal, with fore angles rounded and with one rounded depression, posterior angles less rounded, base depressed, longitudinally deeply and largely depressed in the middle; punctures wide; elytra densely and finely rugulose, subopaque, humeri slightly bulging. Ab- dominal tergites densely setose but with one shiny glabrous spot on each side; sternites glabrous and smooth. Male genitalia: in dorsal view, gonocoxal piece wide in the middle, gonostyli conically narrowed with slender apical lobes; in lateral view, gonocoxal piece wide and short, gonostyli subcylindrical on the basal third or more widened in the middle on ventral margin, then inclined to form a short and stout apical lobe; aedeagus in lateral view with two distanced apical hooks on ventral side, similarly inclined; endophallus hook curved.

Remarks. Species almost unknown. According to the description it seems to have some similarity with T. ottomanus. For this reason, we tentatively assigned it to a subgroup with the Turkish species.

Distribution (Fig. 8d, star). TAJIKISTAN. Tigrovaja balka (Pripisnova, 1987). 


\section{Appendix II. Keys to the species of Trichomeloe}

Males:

1. Male antennomeres III-VII without a modified area (Figs 7b, 7d); aedeagus with one hook. ................................ 2 .

1'. Male antennomeres III-VII with a raised glabrous area (Figs 7a, 7c); aedeagus with two hooks.

2. Pronotum campaniform (Fig. 5c), flat, longer than wide, widely depressed at base; templa parallel, occiput elongate posteriorly; integument black, dark, almost shiny; setae not dense; pronotum and elytra shagreened, head punctures deep; protarsomeres short. conicicollis

2'. Pronotum reniform, slightly convex, as long as wide, basal depression narrower; templa and occiput rounded. Integument dark brown, subopaque, with very dense rufescent setae; punctures of head and pronotum very dense and fine; protarsomeres elongate. .... chrsysocomus

3. Species distributed in Tajikistan (Fig.8d). ............ ovatus

3'. Species distributed in the Near East. ............................... 4.

4. Abdomen with elongate light setae, arranged in tufts, separated by nude areas; head red, except clypeus, ventral side and posteriorly to eye black; integument shiny, head punctation wide and deep; pronotum subpentagonal with smooth and nude raised areas on sides and in the middle.

ottomanus

4'. Abdominal setation uniformly distributed; head with a red frontal spot, usually confined to the middle of frons, in one species (sericellus) more or less extended; pronotum reniform, integument opaque or subopaque. ........ 5 .

5. Head and pronotal setation very short and thick, black.

5'. Body setation light, elongate, fine, recumbent. .............. 6.

6. Head primarily red, the red colouration ever extended on templa, black on the fore part of frons; templa wide; antennomeres V-VII distinctly shorter than III, III-IV slightly widened apically. sericellus

6'. Head black with a small frontal red spot, templa less enlarged; antennomeres V-VII subequal to III, III-IV not widened apically.

7. Integument black opaque; body setae elongate and dense golden yellow; antennomere III shorter than IV; punctures on head and pronotum slightly deep and distanced, intermediate surface umpunctured; head frontal spot transverse; eye dorsally only slightly convex, in lateral view fore margin more incised, longer, narrowed anteriorly; sides of pronotum more obliquely narrowed anteriorly. mesopotamicus

7'. Integument black subopaque or almost shiny; body setae more sparse, shorter, light, but never golden yellow; antennomere III as long as IV; punctures on head and pronotum deep and denser, intermediate surface micropunctured; head frontal spot widened anteriorly, subtriangular or oval; eye dorsally more convex, in lateral view fore margin less incised, shorter and less narrowed anteriorly; sides of pronotum more parallel anteriorly. ....... deflexus
Females:

1. Species from Tajikistan (Fig.8d). ............................ ovatus

1'. Species from Near East. ................................................. 2.

2. Abdomen with elongate light setae, disposed on tufts, spaced out by nude areas; head red, except clypeus, ventral side and posteriorly to eye, which are black; integument shiny, head puncturation wide and deep; pronotum subpentagonal with smooth and nude areas on sides and in the middle. .................................................. ottomanus

2'. Abdominal setation uniformly distributed; head with a red frontal spot, usually confined in the middle of frons, more or less extended in one species (sericellus); pronotum evidently reniform, integument opaque or subopaque. .. 3.

3. Head posteriorly protruded; pronotum longer than wide, flat, conically narrowed anteriorly. ................. conicicollis

3'. Head posteriorly rounded; pronotum as long as wide, slightly convex, evidently reniform, anterior sides curved. 4.

4. Head and pronotum setation very short and thick, black. . syriacus

4'. Body setation light, elongate, fine, recumbent. ............. 5.

5. Head widely red, the red colouration ever extended on templa, black on the fore part of frons. ............ sericellus

5'. Head red spot only in the middle of frons. ..................... 6.

6. Body setae yellow-grey; setae short, sparse; integument piceous, slightly shiny; head frontal spot widened anteriorly, subtriangular or oval. ................................... deflexus

6'. Body setae yellow-rufescent; setae longer and more dense; integument black opaque; head frontal spot transverse.

7. Species from northern Irak ……................ mesopotamicus

7'. Species from Levant and south-eastern Turkey. chrysocomus 


\section{Appendix III. List of examined collections with acronyms used in the text}

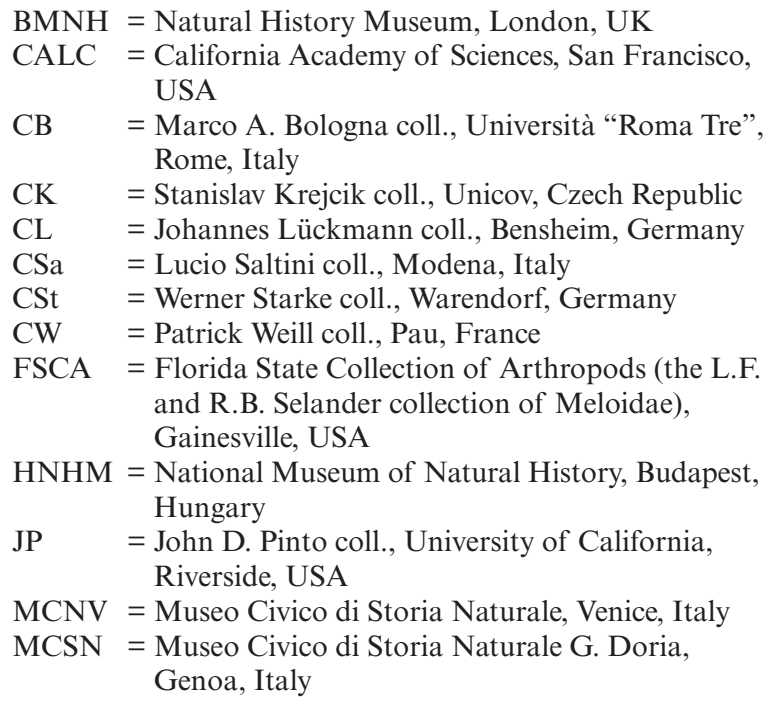

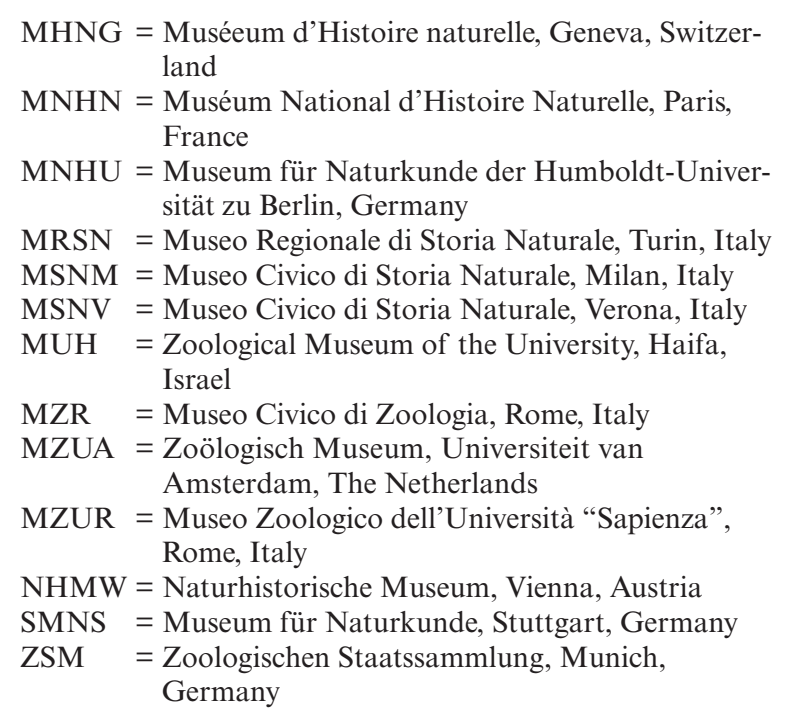
land 